Open Access

\title{
Migrating out of a crowded labor market: evidence from Egypt
}

\author{
Anda David ${ }^{1,2}$ and Joachim Jarreau ${ }^{1 *}$ (D)
}

\author{
*Correspondence: \\ joachim.jarreau@dauphine.fr \\ ${ }^{1}$ PSL Université Paris-Dauphine, PSL \\ Research university, IRD, LEDa, \\ UMR[225], DIAL, 75016 Paris, France \\ Full list of author information is \\ available at the end of the article
}

\begin{abstract}
We analyze the determinants of emigration at the individual and household level, using three waves of the Egyptian labor market panel survey (ELMPS) covering the 1998-2012 period. Exploiting the panel structure of the data allows us to reduce the risk of reverse causality and to estimate the effect of migrant networks more accurately than in studies based on cross-sectional data. We confirm, in the Egyptian context, the non-linear relationship between household resources and migration propensity, due to migration costs; a larger network of past emigrants from the same community mitigates this selection on wealth, increasing the propensity to migrate among poorer households. We also show that unemployment and informal employment act as incentives to emigrate, suggesting that the scarcity of quality jobs, in particular on the skilled labor market, is one important driver of emigration flows in Egypt. However, these incentives turn into effective migration only in communities with a sufficiently large network of past migrants.
\end{abstract}

JEL Classification: J61, O15, F22

Keywords: International migration, Networks, Migrant selection, Formality, Egypt

\section{Introduction}

The labor market in Egypt fails to offer opportunities to the youth. The share of formal jobs has decreased. The public sector has contracted, and education no longer guarantees access to a public job. Entering the labor market is difficult and often requires connections. The World Bank notes that the informal sector was the only source of employment growth in the 1998-2012 period (World Bank 2014). Educational attainment increased during the same period; job prospects have deteriorated in particular for the young educated.

In this context, temporary work migration, mostly to Gulf countries, appears as one solution out of the "Labor market trap", in particular in rural areas and those distant from urban centers where formal jobs concentrate. There were an estimated 3.7 million Egyptian emigrants in 2010. According to the World Bank, "it is reasonable to conclude that the lack of a formal private sector in distant Upper Egypt and the systematic exclusion of recent generations from the public sector has been one driver of international migration."

This paper asks "Who migrates?" in Egypt. A basic model of migration (Borjas 1987) predicts that migration increases with the relative gain, comparing expected income abroad and at home. With credit constraints, however, effective migration also depends

(c) The Author(s), 2017 Open Access This article is distributed under the terms of the Creative Commons Attribution 4.0 International License (http://creativecommons.org/licenses/by/4.0/), which permits unrestricted use, distribution, and reproduction in any medium, provided you give appropriate credit to the original author(s) and the source, provide a link to the Creative Commons license, and indicate if changes were made. 
on the capacity to finance migration costs. Networks of past migrants tend to lower such costs, making migration possible for individuals lower in the income or wealth distribution. ${ }^{1}$

We consider the role of labor market outcomes-employment and formal employment- as potential determinants of the migration decision and the interaction between these outcomes and networks as determinants of migration. We also look at the relationship between household wealth, migrant networks, and the propensity to emigrate. We use data from Egypt's labor market survey, which allows us to observe individual and household characteristics before a migrant's departure, thus mitigating reverse causality. Throughout the paper, we focus on temporary migration, which represents the major part of Egyptian emigration.

Using an index of household wealth as a proxy for permanent income, we confirm the non-linear relationship between wealth and migration propensity, in line with other studies on emigrant selection in developing countries (McKenzie and Rapoport 2007; Fernandez-Huertas Moraga 2013). We also find that migrant networks influence this relationship, increasing migration incidence at lower wealth levels.

We find labor market outcomes-unemployment and informal employment-to feature prominently among the drivers of emigration. Unemployed young men, and those employed in the informal sector, are more likely to emigrate. In the context of Egypt, characterized by high unemployment and informality rates, and a "dual" labor market (Assaad 2014; Wahba and Assaad 2015; Assaad and Krafft 2015), these findings suggest that the scarcity of quality jobs, in particular for educated youth, acts as a driver of migration flows. However, interacting labor market outcomes and migrant networks shows that migration is conditional on the network: the effect of unemployment and informal employment is non-significant or reversed in areas with a low prevalence of migration. This raises the potential concern that opportunities to migrate are unequally shared across communities in Egypt.

A large literature is devoted to the issue of migrant selection, which matters for welfare in both sending and host countries. Numerous papers have studied the question for Mexican migrants, reaching different conclusions as to whether Mexican migrants to the USA are positively or negatively selected (i.e., more or less educated, or productive, than non-migrants) (Chiquiar and Hanson 2005; McKenzie and Rapoport 2007; Moraga 2011; Fernandez-Huertas Moraga 2013). McKenzie and Rapoport (2010) have proposed that variation in the size of networks may explain different patterns of selection because networks help reduce migration costs and overcome credit constraints, reducing positive selection.

Our results show that, in a labor market characterized by high unemployment and duality, employment status is a more relevant indicator of migration incentives than home wages. Unemployment and informality are drivers of migration, but their effect is also conditional on networks. A possible explanation is that migration intentions fail to materialize in low-migration environments due to cost or credit constraints.

The importance of international migration in Egypt is highlighted by the extensive research on the impact of migration on the Egyptian labor market, both in terms of entrepreneurship and labor market outcomes of returnees (McCormick and Wahba 2001; 2003; Wahba 2007; Wahba and Zenou 2012; Wahba 2015) and of impacts on nonmigrants (Binzel and Assaad 2011; Bertoli and Marchetta 2015). Comparatively, less work 
has been devoted to the determinants of departures. Amer and Fargues (2014) analyze migration intentions of young Egyptians after the 2011 uprising and find that the perception of increased insecurity and political instability following the revolution act as a new push factor for migration. This paper, focused on the economic drivers, shows the importance of local economic conditions as a driver of emigration. Recent reports (World Bank 2014) highlight the increasing difficulty of graduates to find jobs matching their qualifications, as the reduction of public sector jobs has not been compensated by private sector job growth. The results presented here suggest this feature of the labor market to be one important driver of Egyptian emigration flows.

The paper is organized as follows: Section 2 presents the data we use and describes our methodological approach, Section 3 presents our findings, and Section 4 concludes.

\section{Context, data, and methodology}

International migration has become a prominent feature of the Egyptian economy since its start in the 1970s. According to CAPMAS, the Egyptian statistical agency, there were 3.7 million Egyptian emigrants in 2010. The majority are temporary migrants (70\%, according to CAPMAS), who go to oil economies of the Gulf, Libya, and Jordan, to work. The amount of remittances sent by migrants amounted in 2010 to $\$ 7.7$ billion., representing $4 \%$ of the GDP.

The majority of Egyptian migrants are men, who go to countries in the Gulf region, Libya, and Jordan as temporary migrants to work ${ }^{2}$. Among current migrants in 2012,96\% are men, $95 \%$ of them are working abroad. Saudi Arabia, Jordan, Kuwait, and Libya make up $75 \%$ of all destinations. The median current migrant has been abroad for 4 years.

Therefore, we will restrict our analysis to men and model migration as a decision in which household variables such as size and financial capacity are potential determinants. The concentration in destination countries implies that networks of past migrants are likely to play a role.

\subsection{Data and descriptive statistics}

We use the 1998, 2006, and 2012 waves of the Egyptian Labour market panel survey $(\text { ELMPS })^{3}$, a nationally representative household survey carried out by the Economic Research Forum (ERF), in cooperation with the Central Agency for Public Mobilization and Statistics (CAPMAS) (OAMDI 2016).

The survey provides information on past migration as well as on current migration (in the 2006 and 2012 waves); in addition, the 2012 survey contains a detailed module on migration. This makes this survey particularly well suited for the study of migration issues. In this paper, we exploit the longitudinal structure of the data, which allows to look at pre-departure determinants of emigration (at the individual and household levels); this mitigates the reverse causality issues which arise when using cross-sectional data to study these questions.

In order to study the determinants of emigration, we construct two distinct samples.

In the first one (sample I), we match household characteristics in 1998 and 2006 to later departures of one of its members. We use information from the following survey wave (2006 and 2012, respectively) on current and return migrants to identify households where a member emigrated between one survey year and the next (by the next survey year, the migrant may have returned or not). By matching emigration episodes to pre- 
departure variables, we are able to study the determinants of emigration, while avoiding reverse causality: this is particularly important when looking at household wealth as a determinant of migration. Sample I is thus a panel of households with two periods.

The second sample (sample II) consists of observations for individuals living in Egypt in 2006, where we use the information in the following 2012 survey to identify those who emigrated after 2006 (i.e., between 2007 and 2012). We use this sample to look at the predeparture determinants of emigration, at the individual and household level. Given the gender and age distribution in the migrant population, we retain in this sample only men of age between 16 and 54, i.e., potential emigrants.

The advantage of this sample is that we can look at the impact of individual characteristics, such as education, age, and employment, on emigration decisions; while in the first sample, we use only household-level variables. The limitation, however, is that we cannot build a similar sample for individuals who emigrated between 1998 and 2006, as the 2006 survey provides little information on current migrants in that year (gender and age are not available). Therefore, sample II is a cross section of individuals in 2006.

Statistics on the household sample (sample I) are presented in Table 1.

Households with a member emigrating in the following years appear similar to other households, in terms of education of the head, wealth, and dependency ratio (measured as the share of non-working individuals in the household). For wealth, we use an asset-based index, built as the principal component of a list of assets and asset characteristics owned by the household; this serves as a proxy for a household's permanent income (Filmer and Pritchett 2001).

Migrant households are more often rural; they are significantly larger, and they have a significant lower shares of members employed in the formal sector.

Migrant households are more likely to reside in localities with a history of recent migration: this is consistent with the evidence on the role of networks in migration. As a measure of the potential migrant network, we use the migration prevalence (share of households with a migrant) at the district level, based on recent departures (1998-2005 departures for the 2006 wave, 1990-1997 for the 1998 wave).

Table 2 presents descriptive statistics for the sample of individuals (sample II): focusing on men aged between 16 and 54 in 2006, it compares the characteristics of individuals who emigrated after 2006, to those who did not.

Table 1 Descriptive statistics at the household level (sample l)

\begin{tabular}{|c|c|c|c|c|}
\hline & & Migrant households & Non-migrant households & Difference \\
\hline Male-headed household & & $83.3 \%$ & $82.8 \%$ & \\
\hline Household size & & 5.7 & 4.8 & $* * *$ \\
\hline Urban & & $30.2 \%$ & $48.3 \%$ & $* * *$ \\
\hline Years of schooling (household head) & & 6.6 & 6.9 & \\
\hline Wealth score & & -0.016 & -0.026 & \\
\hline Dependency ratio & & 0.7 & 0.7 & \\
\hline Share of members working in the formal sector & & 0.12 & 0.15 & $* * *$ \\
\hline $\begin{array}{l}\text { Network (migration prevalence, } \\
\text { district-level) }\end{array}$ & & 0.06 & 0.03 & $* * *$ \\
\hline \multirow[t]{3}{*}{ Number of observations } & & 464 & 9807 & \\
\hline & 1998 & 124 & 3,527 & \\
\hline & 2006 & 340 & 6,280 & \\
\hline
\end{tabular}

*** Indicates rejection at $1 \%$ in $t$ test of equality of means 
Table 2 Descriptive statistics at the individual level (sample II)

\begin{tabular}{|c|c|c|c|c|}
\hline & & Migrants & Non-migrants & Difference \\
\hline \multicolumn{5}{|l|}{ Education } \\
\hline & No education & $15.5 \%$ & $25.2 \%$ & $* * *$ \\
\hline & Primary or less & $8.5 \%$ & $16.6 \%$ & $* * *$ \\
\hline & Secondary & $50.7 \%$ & $34.1 \%$ & $* * *$ \\
\hline & Tertiary & $25.2 \%$ & $24.0 \%$ & \\
\hline Network & & $8.4 \%$ & $4.8 \%$ & $* * *$ \\
\hline Wealth & & -0.06 & -0.01 & \\
\hline \multicolumn{5}{|l|}{ Labor status (before migration) } \\
\hline & Working & $70.4 \%$ & $77.0 \%$ & $* * *$ \\
\hline & Unemployed & $22.8 \%$ & $4.9 \%$ & $* * *$ \\
\hline & Inactive & $6.7 \%$ & $18.1 \%$ & $* * *$ \\
\hline Formal work (before migration) & & $13.7 \%$ & $35.1 \%$ & $* * *$ \\
\hline Age & & 25.1 & 30.9 & $* * *$ \\
\hline Household size & & 6.1 & 5.7 & $* *$ \\
\hline Number of observations & & 435 & 7,730 & \\
\hline
\end{tabular}

Future emigrants are markedly more educated than the average. More than half of them have secondary education, and a quarter have tertiary education. We have here a first indication of the positive selection of Egyptian emigrants, which is also highlighted in Wahba (2015). In terms of labor market outcomes, future emigrants appear to have significantly higher unemployment rates, and their jobs are more often in the informal sector. This confirms the negative association between formal employment and migration, already shown in the household data. We will thus give a particular attention to these aspects in the analysis of factors determining the migration decision.

Migrants are markedly younger than non-migrants. The average age of migrants in our sample (as measured in 2006, i.e., a few years before migration) is $25 ; 14 \%$ were aged 16 to 19 in 2006.

\subsubsection{Wealth-migration relationship}

Before turning to the regression analysis, we look more closely at the relationship between (pre-departure) wealth and migration, using the household sample. This is done in Figs. 1, 2, and 3, which compare the distribution of the wealth variable in the population of soon-to-be migrant households and in the whole population. The wealth variable is a standardized index based on asset ownership (Filmer and Pritchett 2001). It has a mean of 0 and a standard deviation of 1 , in the whole population. Figure 1 shows that the probability to send a migrant, in the few years following the survey, is higher in an interval of approximate wealth values $[-1,0]$. In other words, households most likely to send a migrant belong to what might be called a lower middle class. This is in line with previous analysis of migration determinants, which showed that migration tend to be more prevalent among relatively welloff households, because it requires a certain level of wealth or income in order to afford migration costs (Fernandez-Huertas Moraga 2013; McKenzie and Rapoport 2007). On the other hand, incentives to migrate decrease with wealth, which explains that the propensity declines in the upper half of the distribution. 


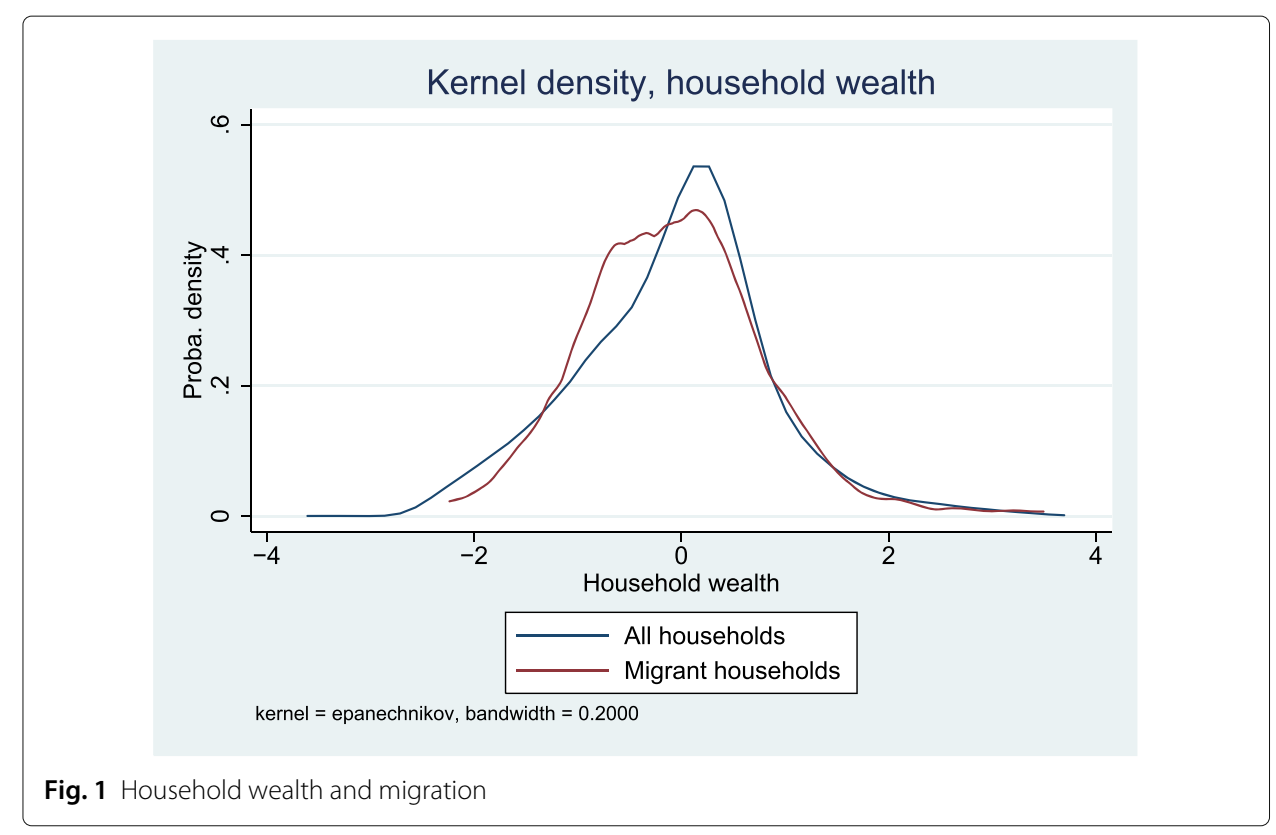

Figures 2 and 3 show that this pattern differs markedly between urban and rural locations. Selection on wealth is more marked in urban populations, where migration is relatively more likely among households above mean wealth. By contrast, in rural areas, migration prevalence is highest for households within one standard deviation below mean.

Finally, Figs. 4, 5, and 6 display the distributions of wealth post-departure, in 2012, comparing again households with a migrant departure between 2007 and 2012, with the whole population. These figures show a marked shift in the distribution for migrant households. Although such graphic display does not allow to infer a causal relationship, it suggests that migration is potentially associated with an increase in relative wealth.

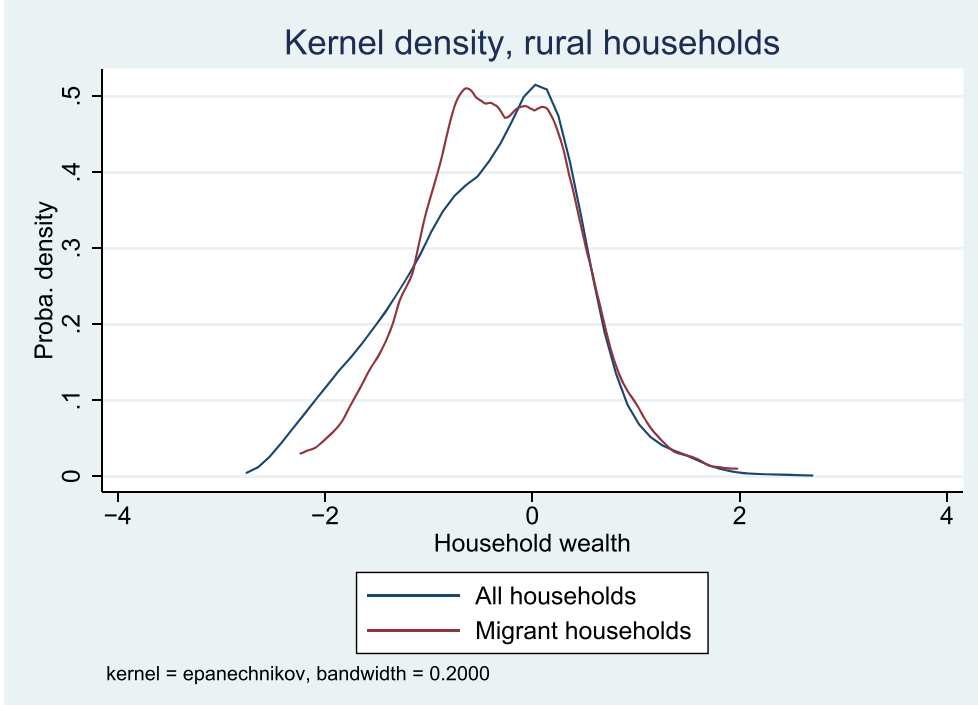

Fig. 2 Household wealth and migration: rural households 


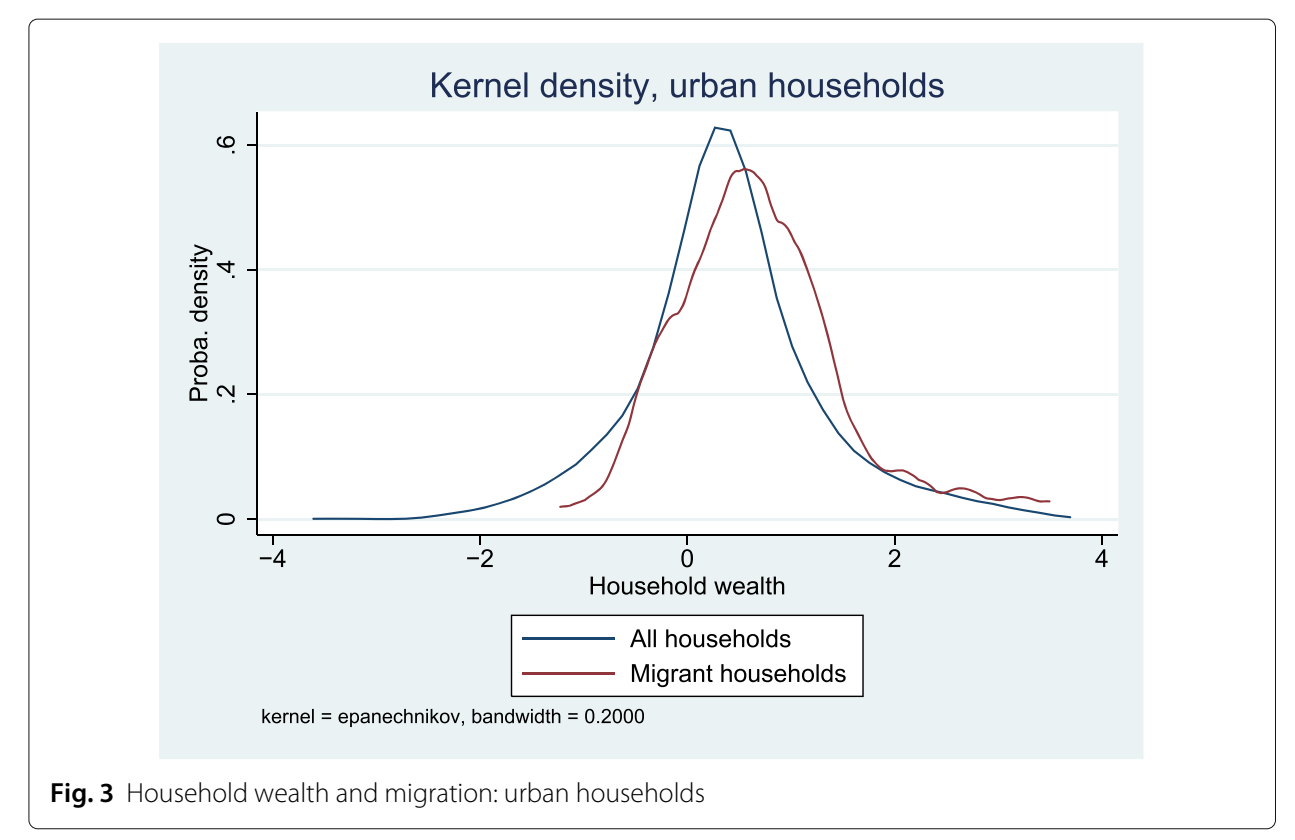

In the next section, we will analyze the determinants of migration, using regression analysis with the same approach, looking at household and individual characteristics before the migrant's departure.

\subsection{Empirical methodology}

The previous section has illustrated the non-linear relationship between a household's level of wealth, and the probability that one member of this household will emigrate in the near future. Next, we will employ an econometric model to study this relationship more precisely, controlling for other characteristics of the household. We will include the interaction between the network of past migrants from the same locality, and wealth, as

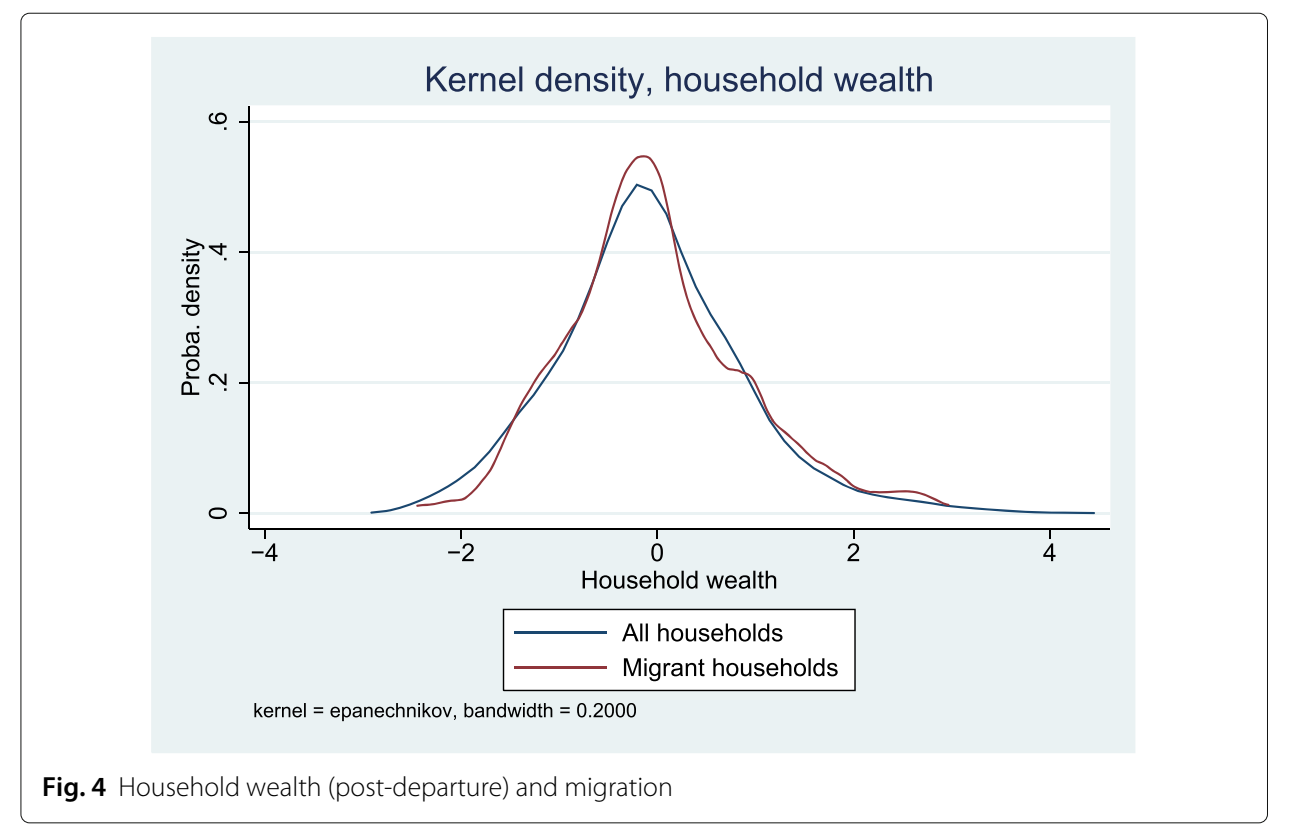




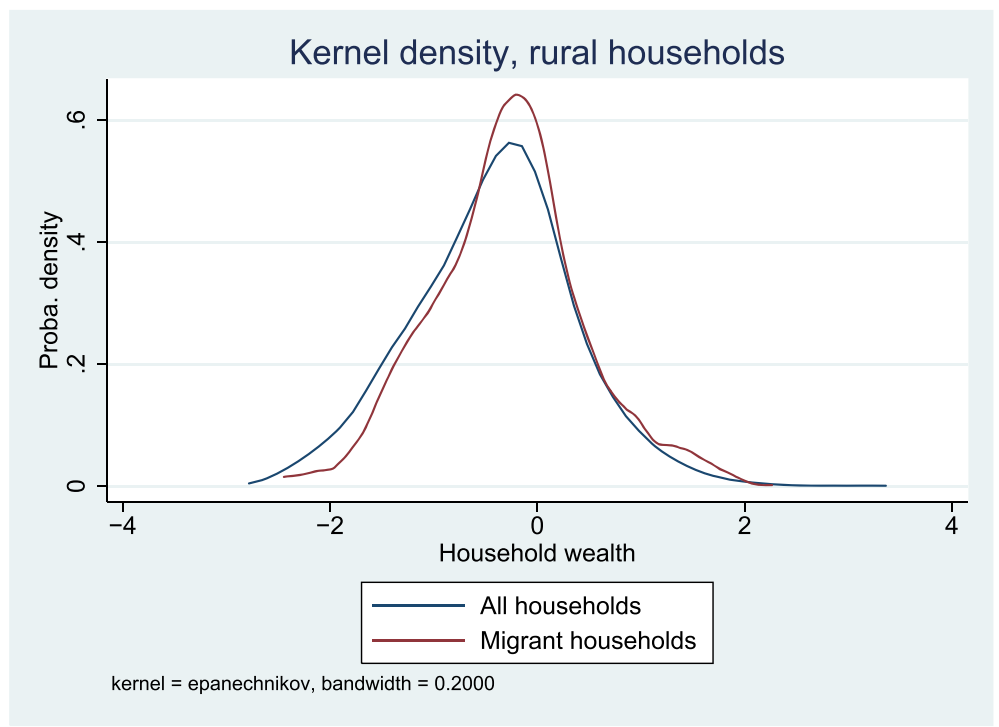

Fig. 5 Post-departure household wealth and migration: rural households

determinants of the propensity to migrate. Following McKenzie and Rapoport (2007), we use a model of migration decision, which includes a measure of households' wealth level in polynomial form (degree 2), interacted with a measure of the local migration prevalence, capturing network effects facilitating migration. ${ }^{5}$ In addition, we will consider labor market outcomes and their interaction with wealth, as determinants of migration.

Our measure of wealth is the same as in the previous section, a standardized index of assets owned by the household, which serves as a proxy for permanent income. As Filmer and Pritchett (2001) show, this type of indicator is a more stable measure of a household's standard of living than income; they advocate its use as a proxy for household's long-term income ${ }^{6}$.

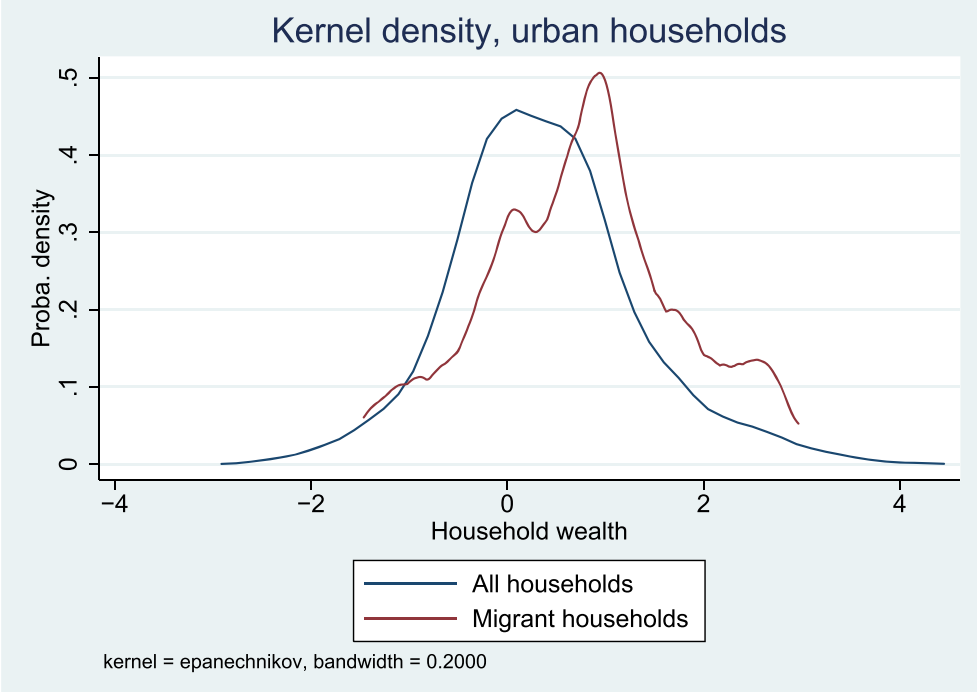

Fig. 6 Post-departure household wealth and migration: urban households 
As a measure of migration prevalence, we will use the share of households in the district, with a member who migrated abroad during the 7-year period before the survey year (this period will differ for the two different samples used, as explained in the following sections devoted to each sample in turn). As explained by Munshi (2015), measuring the impact of network of past migrants on subsequent migration decisions, which is made possible by the use of panel data, helps to reduce endogeneity.

Beyond the role of wealth, we are also interested in the impact of labor market outcomes on the propensity to emigrate. The models will include a measure of employment and of formal employment, at the household or the individual level.

The next subsections present each model in turn: we apply the first to the sample of households (sample I), to measure the impact of household characteristics, on the probability of a subsequent departure of one member abroad. The second model applies the same logic to the sample of individuals (sample II).

\subsubsection{Household-level determinants of the migration decision}

We model the probability that one member of a household will emigrate as a function of pre-departure characteristics.

Our baseline specification is the following:

$$
\operatorname{Mig}_{i, t+1}=\alpha+\beta \cdot W_{i, t}+\chi \cdot N_{i, t}+\delta \cdot N_{i, t} \cdot W_{i, t}+\gamma \cdot X_{i, t}+\gamma_{g}+\epsilon_{i, t}
$$

with $t=\{1998 ; 2006\}$ and $M i g_{i, t+1}$ the dummy variable taking the value 1 if the household $i$ participated in international migration (i.e., at least one member in the household emigrated) between 1999 and 2006 (if $t=1998$ ) or between 2007 and 2012 (if $t=2006$ ) and 0 if not. $X_{i, t}$ is a set of household-level variables, including its size, share of dependents, share of working-age men, and the gender and education level of the head. $\gamma_{g}$ denote governorate fixed-effects.

We estimate this specification as a linear probability model in OLS or IV. In addition, we check that our results hold when using a probit or IV-probit model. Results are quantitatively similar and are presented in the appendix.

The wealth indicator $W$ is a composite asset-based index of wealth, computed as the first component of a vector of assets and durable goods.

Since we restrict the migration timing to the period after the wealth (as well as the other household characteristics) was observed, we avoid the reverse causality bias due to migration impacting wealth ${ }^{7}$.

Our measure for the migration network, $N_{i, t}$, is the migration rate at the district level, defined as the share of households with a member who emigrated abroad during the 7year period before the survey year. ${ }^{8}$ Through the networks effect, an individual living in a district with a high migration rate, should be more prone to emigrate, since this can lower migration costs. ${ }^{9}$

The introduction of this network variable in the model raises two issues. First, there is a concern that this migration rate is measured with error, in particular in districts with few surveyed households. In the household sample considered here (sample I), the number of surveyed households per district has a median value of 49. In order to address this issue, we exclude from the sample observations in districts where less than 20 households were surveyed (less than $5 \%$ of observations). 
The second issue is the risk of omitted variable bias, which may still be present if district-level determinants of migration are persistent in time, even though we use lagged migration rates as regressor and future departures as dependent variable. To address this issue, we use an instrumental variable approach, and we instrument the migration prevalence with older migration rates, using the fact that departures tend to be more frequent in places where historic migration rates have been higher. For this model, we use the migration networks computed from the previous survey round. Precisely, if $t=2006$, we instrument the migration prevalence for 1998-2005 departures using the local migration prevalence computed on pre-1998 departures ${ }^{10}$.

We introduce an interaction term between wealth and network to capture the possibility that, as migrant networks lower the costs of migration, the level of wealth necessary to be able to send a migrant decreases. If this is the case, then the coefficient on the interaction terms should be negative ${ }^{11}$.

Moreover, the graphical analysis in Figs. 1, 2, and 3 suggests a non-linear relationship between wealth and migration. To allow for this possibility, we will use a specification including polynomial terms in wealth, and interactions with the network variable:

$$
\operatorname{Mig}_{i, t+1}=\alpha+\beta_{1} \cdot W_{i, t}+\beta_{2} \cdot W_{i, t}^{2}+\chi \cdot N_{i, t}+\delta_{1} \cdot N_{i, t} \cdot W_{i, t}+\delta_{2} \cdot N_{i, t} \cdot W_{i, t}^{2}+\gamma \cdot X_{i, t}+\gamma_{g}+\epsilon_{i, t}
$$

We also expect determinants of migration to differ in rural and urban environments. Migration is higher in rural areas, as shown in descriptive statistics. There are also indications that job market prospects deteriorate with distance to the urban centers where public and formal jobs concentrate (e.g., World Bank (2014)). To examine this possibility, we will estimate the model separately on the subsamples of urban and rural households.

\subsubsection{Individual determinants of the migration decision}

In a second approach, we use our sample of individuals. As explained in Section 2.1, we focus here on the cross section of men of working age observed in 2006, among whom we identify individuals who emigrated after this date. This allows us to estimate the probability of emigration (between 2007 and 2012), given pre-migration characteristics. The model we estimate is the following:

$$
\begin{aligned}
\operatorname{Mig}_{i, 2007-2012}= & \alpha+\beta_{1} \cdot W_{i, 2006}+\beta_{2} \cdot W_{i, 2006}^{2}+\chi \cdot N_{i, 2006}+\delta_{1} \cdot N_{i, 2006} \cdot W_{i, 2006}+ \\
& +\delta_{2} \cdot N_{i, 2006} \cdot W_{i, 2006}^{2}+\gamma \cdot X_{i, 2006}+\gamma_{g}+\epsilon_{i, 2006}
\end{aligned}
$$

with $\mathrm{Mig}_{i, 2007-2012}$ a dummy variable taking the value 1 if an individual observed in 2006 has emigrated between 2007 and 2012 and 0 if not. $W_{i, 2006}$ is the wealth indicator of the household to which the individual $i$ belongs; it is introduced in polynomial form in order to allow for a non-linear relation on the propensity to migrate, as suggested by the descriptive analysis presented in the previous section.

$N_{i, 2006}$ is our measure of the migration network, which is defined in the same way as for the household model, as the share of households with a member who emigrated during 1998-2005. As with sample I, we use migration prevalence based on older departures (1990-1998) as an instrument. $X_{i, 2006}$ is a vector of individual characteristics.

As with sample I, we address the concern of measurement error in the network $N_{i, 2006}$ variable, by restricting the sample to observations in districts with more than 25 households surveyed in 2006. 
In order to capture the labor market failures that might act as push factors, we will focus on particular on unemployment and employment characteristics.

As for the household model, we expect the impact of these factors to possibly differ in urban and rural areas and will estimate the model separately for urban and rural individuals.

We will also estimate this specification using a linear probability model in OLS and IV. As a robustness check, we use probit and IV-probit models and report the results in the appendix.

\section{Results}

\subsection{Sample I: household model}

We first analyze the determinants of the migration decision at the household level. We estimate the impact of the households' characteristics in 1998 and 2006, on the probability that one member migrates abroad in the period 1999-2006 and 2007-2012, respectively.

Table 3 presents results from the base model. In columns 1 and 2, we use a model without the variables dependency and number of working-age men. These variables are potential determinants of the migration decision, but they could also be endogenous. We compare estimates with and without these variables and verify that coefficients on other variables are virtually unaffected by their inclusion. Measuring these characteristics before migration is likely to help mitigate the endogeneity risk.

Columns 3 and 4 estimate the full model in OLS and in IV. The measured coefficient on our network variable-defined as the migration prevalence at district level-is larger in IV. This may be due to measurement error. ${ }^{12}$

IV results (column 4) indicate that an increase in the prevalence of migration in a household's district (i.e., the share of households with one migrant having left in the years preceding the survey) by $10 \%$ is associated with a $12 \%$ higher probability that one household member will migrate abroad. This impact seems to be larger in rural areas.

Household wealth is positively associated with the probability to send a migrant abroad. This is in line with the literature and is consistent with the hypothesis that higher wealth helps to finance the migration of a member, which is costly.

Our network variable has a standard deviation of 0.051 . Thus, an increase by one standard deviation of migration prevalence in a district raises the probability to emigrate by 6 percentage points $(1.19 * 0.051$, based on IV results of column 6). By contrast, a one-standard deviation increase in wealth raises this probability by 1.8 percentage points (wealth being a standardized variable), i.e., a less than three times smaller impact. This indicates the important magnitude of the effect of networks in favoring migration.

The share of working-age men (a measure of the pool of potential migrants in the household) are both positively associated with the probability of sending a migrant. The household's dependency ratio, computed as the ratio between economically inactive and active members increases the propensity to send a migrant, suggesting that it may act as an additional incentive to search a job abroad. The education level of the household head does not significantly impact the migration propensity; this might be due to the fact that it is correlated to the wealth index. 


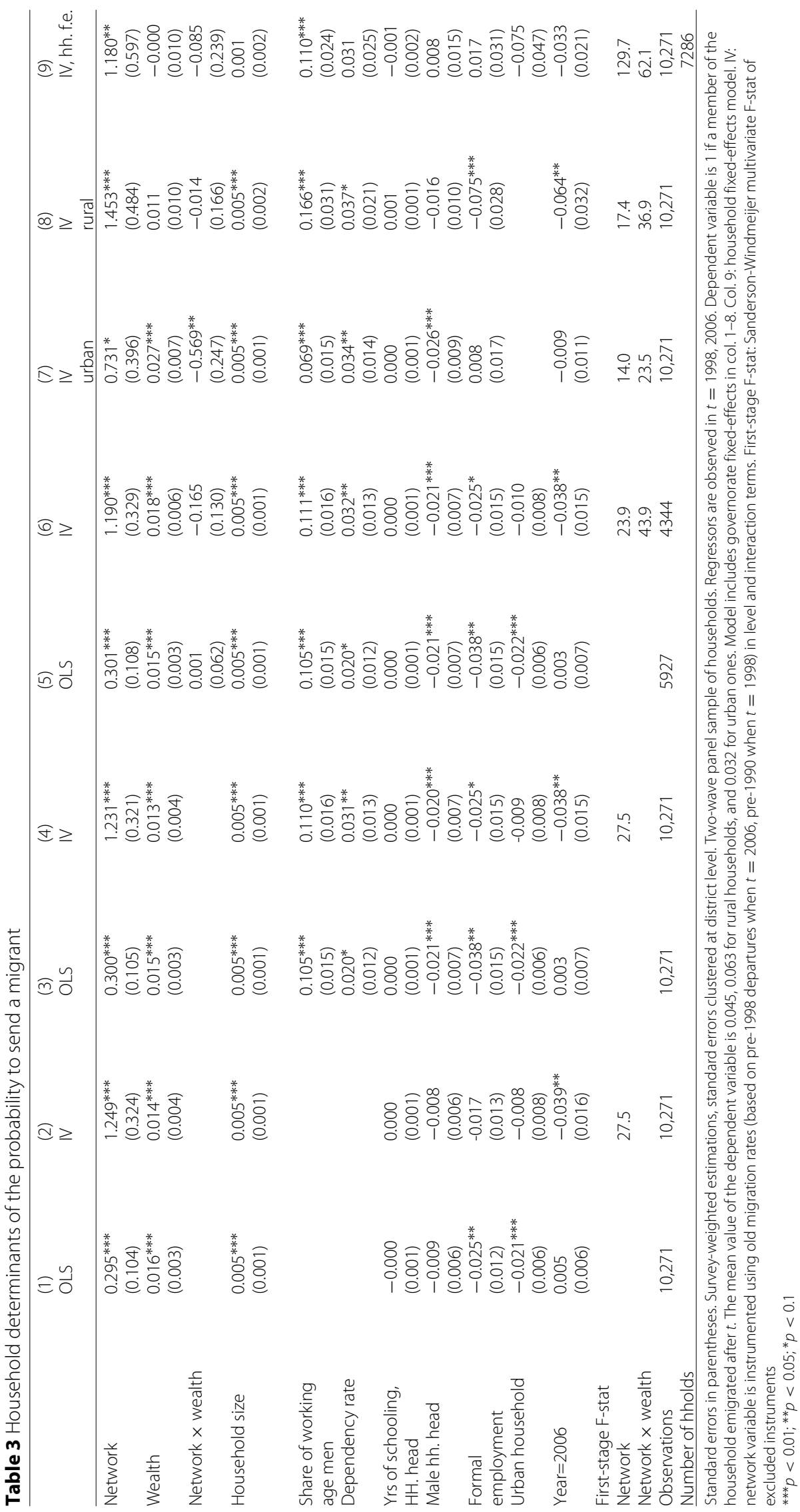


The share of household members employed in the formal sector (formal employment) is negatively associated with the probability to send a migrant. We may expect the access to formal jobs to influence migration decisions in two ways. On the one hand, it could facilitate migration, if wages paid in the formal sector are higher, or if formality reduces credit constraints, making the payment of migration costs easier. On the other hand, benefits associated with formal jobs, including stability and other non-wage benefits, may act as a disincentive to leave. This seems particularly relevant in the context of Egypt, where a large share of formal jobs consist of public jobs (68\%, as of 2012), and where the market for skilled employment in the public sector is characterized by heavy rationing (Assaad 2014). Our results suggest that the second effect dominates. We examine further the role of labor market outcomes in the next set of results.

In column 9, we estimate the model in household panel form, using household fixed effects. This implies that we now estimate the effect of changes in variables within a household, between 1998 and 2006, on the probability to have one member migrating abroad. The effect of several variables including wealth, dependency, and the formal employment share are no longer significant in this model. Most of the effects presented in the other columns are therefore identified based on between-household variation, while within-household changes over the period do not generate detectable effects.

In Table 4, we look closer at the role of labor market outcomes (unemployment and formal employment) and their interaction with the migrant network.

Concerning unemployment, our results show that a higher share of unemployment decreases the migration propensity, with the effect reversed when the network increases. This suggests that unemployment not only acts as an incentive to emigrate but also limits the capacity to finance migration; so that a more developed migrant network allows high-unemployment households to send migrants abroad.

Specifically, the mean value of networks in the sample is 0.031 . In a district with no previous history of migration (network $=0$ ), a share of unemployed among members higher by $10 \%$ slightly decreases the probability to send a migrant abroad, by about $1 \%$. This effect becomes positive approximately at the mean value of networks $(3.97 * 0.031=$ 0.12). In high network districts (i.e., above average), the incentive effect dominates, so that higher unemployment increases the propensity to emigrate.

Column 2 shows that the formal employment share decreases migration, the more so in high-network areas, with no evidence of a positive effect at low or zero network value. This confirms that formal employment acts mainly as a disincentive for emigration.

Non-linear effect of wealth Figures 1,2, and 3 suggest that the effect of wealth on the propensity to emigrate is non-linear. To allow for this possibility, we now enrich the specification of the household model of migration using a polynomial in wealth (of degree 2), with interactions with the network variable. Results are displayed in Table 5.

These results confirm the non-linear effect of wealth, as well as the influence of networks in this relationship. Coefficients on wealth and its square are both positive: thus, in a locality with low networks (low past migration prevalence), migration propensity increases monotonously with wealth. Networks tend to mitigate the impact of wealth, which is consistent with the idea that they lower the costs of migration. In localities with a larger network, the migration-wealth relationship has an inverted U shape, with the 
Table 4 Determinants of migration: unemployment and formality (IV estimates)

\begin{tabular}{|c|c|c|}
\hline & (1) & $(2)$ \\
\hline \multirow[t]{2}{*}{ Network } & $1.113^{* * *}$ & $1.226^{* * *}$ \\
\hline & $(0.306)$ & $(0.277)$ \\
\hline \multirow[t]{2}{*}{ Wealth } & $0.012^{* * *}$ & $0.012^{* * *}$ \\
\hline & $(0.004)$ & $(0.004)$ \\
\hline Unemployment & $-0.109^{* *}$ & $-0.107^{* *}$ \\
\hline (share) & $(0.049)$ & $(0.050)$ \\
\hline \multirow[t]{2}{*}{ Unemployment $\times$ network } & $3.969^{* *}$ & $3.897^{* *}$ \\
\hline & $(1.906)$ & $(1.910)$ \\
\hline Formal employment & $-0.027^{*}$ & 0.010 \\
\hline (share) & $(0.015)$ & $(0.026)$ \\
\hline \multirow[t]{2}{*}{ Formal $\times$ network } & & $-1.319^{*}$ \\
\hline & & $(0.791)$ \\
\hline \multirow[t]{2}{*}{ Household size } & $0.005^{* * *}$ & $0.005^{* * *}$ \\
\hline & $(0.001)$ & $(0.001)$ \\
\hline \multirow[t]{2}{*}{ Share of working-age men } & $0.112^{* * *}$ & $0.114^{* * *}$ \\
\hline & $(0.017)$ & $(0.017)$ \\
\hline \multirow[t]{2}{*}{ Years of schooling, $\mathrm{HH}$. head } & 0.000 & 0.000 \\
\hline & $(0.001)$ & $(0.001)$ \\
\hline \multicolumn{3}{|l|}{ First-stage F-stat } \\
\hline Network & 35.9 & 50.8 \\
\hline Network $\times$ unemp. & 20.5 & 19.7 \\
\hline Network $\times$ formal & & 23.2 \\
\hline Observations & 10,271 & 10,271 \\
\hline
\end{tabular}

Standard errors in parentheses. Survey-weighted estimations, standard errors clustered at district level. Two-wave panel sample of households. Regressors are observed in $t=1998,2006$. Dependent variable is 1 if a member of the household emigrated after $t$. The mean value of the dependent variable is 0.045 . Model includes governorate fixed-effects and the controls: urban, year, dependency, share of working-age men, Male hh. head. IV: network variable is instrumented using old migration rates (based on pre-1998 departures when $t=2006$, pre-1990 when $t=1998$ ) in level and interaction terms. First-stage F-stat:

Sanderson-Windmeijer multivariate F-stat of excluded instruments

${ }^{* * *} p<0.01 ;{ }^{* *} p<0.05 ;{ }^{*} p<0.1$

location of the maximum decreasing with the value of the network variable. ${ }^{13}$ This confirms that network effects tend to counterbalance the positive selection of emigrants on wealth.

Results in the appendix confirm that results reported in Tables 3, 4, and 5 hold when using a probit or IV-probit model.

\subsection{Sample II: individual model}

The results for the individual model are presented in Tables 6, 7, and 8 .

We now use the sample of individuals observed in 2006, constructed as explained in Section 2.1. In this sample, only $3.7 \%$ of migrants are women; $95 \%$ of migrants in the sample were between 16 and 54 years old in 2006. Therefore, the estimations are conducted on the sample of men aged 16 to 54 years in 2006.

The dependent variable is the probability of an individual's departure abroad between 2007 and 2012 (whether he has returned or not); regressors are a set of individual and household variables observed in 2006 before a potential departure.

In Table 6, we estimate the non-linear relationship between wealth and migration prevalence using a polynomial in wealth, interacted with our measure of migrant networks 
Table 5 Household determinants: with wealth polynomial

\begin{tabular}{|c|c|c|c|c|c|}
\hline & (1) & (2) & (3) & (4) & (5) \\
\hline & OLS & IV & IV & IV & IV, household panel \\
\hline & & & Urban & Rural & Fixed effects \\
\hline \multirow[t]{2}{*}{ Network } & $0.419^{* * *}$ & $1.599 * * *$ & $1.329^{* * *}$ & $1.750 * * *$ & $1.265^{* *}$ \\
\hline & $(0.130)$ & $(0.378)$ & $(0.509)$ & $(0.528)$ & $(0.620)$ \\
\hline \multirow[t]{2}{*}{ Wealth } & $0.016^{* * *}$ & $0.017^{* * *}$ & $0.013^{* *}$ & 0.013 & -0.000 \\
\hline & $(0.003)$ & $(0.006)$ & $(0.005)$ & $(0.011)$ & $(0.010)$ \\
\hline \multirow[t]{2}{*}{ Wealth² } & $0.004^{*}$ & $0.016^{* * *}$ & $0.024^{* *}$ & 0.012 & 0.006 \\
\hline & $(0.003)$ & $(0.006)$ & $(0.012)$ & $(0.008)$ & $(0.009)$ \\
\hline \multirow[t]{2}{*}{ Network $\times$ wealth } & $-0.127^{*}$ & $-0.377^{* *}$ & -0.162 & $-0.329^{*}$ & -0.129 \\
\hline & $(0.065)$ & $(0.156)$ & $(0.218)$ & $(0.198)$ & $(0.247)$ \\
\hline \multirow[t]{2}{*}{ Network $\times$ wealth $^{2}$} & $-0.183^{* * *}$ & $-0.563^{* * *}$ & $-0.830^{* *}$ & $-0.498^{* * *}$ & -0.097 \\
\hline & $(0.046)$ & $(0.148)$ & $(0.381)$ & $(0.156)$ & $(0.227)$ \\
\hline \multirow[t]{2}{*}{ Household size } & $0.005^{* * *}$ & $0.005^{* * *}$ & $0.004^{* * *}$ & $0.005^{* * *}$ & 0.001 \\
\hline & $(0.001)$ & $(0.001)$ & $(0.001)$ & $(0.002)$ & $(0.002)$ \\
\hline \multirow[t]{2}{*}{ Share of working-age men } & $0.105^{* * *}$ & $0.111^{* * *}$ & $0.071^{* * *}$ & $0.162^{* * *}$ & $0.110^{* * *}$ \\
\hline & $(0.015)$ & $(0.016)$ & $(0.015)$ & $(0.031)$ & $(0.024)$ \\
\hline \multirow[t]{2}{*}{ Dependency rate } & $0.022^{*}$ & $0.036^{* * *}$ & $0.040^{* * *}$ & $0.038^{*}$ & 0.032 \\
\hline & $(0.012)$ & $(0.014)$ & $(0.015)$ & $(0.022)$ & $(0.025)$ \\
\hline \multirow[t]{2}{*}{ Years of schooling, HH. head } & 0.000 & 0.000 & 0.000 & 0.001 & -0.001 \\
\hline & $(0.001)$ & $(0.001)$ & $(0.001)$ & $(0.001)$ & $(0.002)$ \\
\hline \multirow[t]{2}{*}{ Male hh. head } & $-0.021^{* * *}$ & $-0.019^{* * *}$ & $-0.024^{* * *}$ & -0.016 & 0.009 \\
\hline & $(0.007)$ & $(0.007)$ & $(0.009)$ & $(0.011)$ & $(0.015)$ \\
\hline \multirow[t]{2}{*}{ Formal employment } & $-0.036^{* *}$ & -0.019 & 0.011 & $-0.063^{* *}$ & 0.017 \\
\hline & $(0.015)$ & $(0.015)$ & $(0.017)$ & $(0.028)$ & $(0.031)$ \\
\hline \multirow[t]{2}{*}{ Urban household } & $-0.022^{* * *}$ & -0.008 & & & -0.076 \\
\hline & $(0.006)$ & $(0.009)$ & & & $(0.047)$ \\
\hline \multirow[t]{2}{*}{ Year $=2006$} & 0.004 & $-0.035^{* *}$ & -0.010 & $-0.062^{* *}$ & -0.034 \\
\hline & $(0.007)$ & $(0.015)$ & $(0.012)$ & $(0.032)$ & $(0.021)$ \\
\hline First-stage F-stat: network & & 26.8 & 14.1 & 22.3 & 25.0 \\
\hline Network $\times$ wealth & & 32.5 & 23.5 & 38.4 & 165.5 \\
\hline Network $\times$ wealth ${ }^{2}$ & & 17.9 & 8.9 & 26.5 & 85.1 \\
\hline Observations & 10,271 & 10,271 & 5927 & 4344 & 10,271 \\
\hline Number of hholds & & & & & 7286 \\
\hline \multicolumn{6}{|c|}{$\begin{array}{l}\text { Standard errors in parentheses. Survey-weighted estimations, standard errors clustered at district level. Two-wave panel sample of } \\
\text { households. Regressors are observed in } t=1998,2006 \text {. Dependent variable is } 1 \text { if a member of the household emigrated after } t \text {. } \\
\text { The mean value of the dependent variable is } 0.045,0.063 \text { for rural households, and } 0.032 \text { for urban ones } \\
\text { Model includes governorate fixed-effects except in column } 5 \text {. IV: network variable is instrumented using old migration rates } \\
\text { (based on pre-1998 departures when } t=2006 \text {, pre-1990 when } t=1998 \text { ) in level and interaction terms. First-stage F-stat: } \\
\text { Sanderson-Windmeijer multivariate F-stat of excluded instruments in columns } 2-4 \\
* * * 0<0.01 ;{ }^{* *} p<0.05 ;{ }^{*} p<0.1\end{array}$} \\
\hline
\end{tabular}

(migration rates at the district level, counting departures up to 8 years before 2006). Consistent with results on the household model (sample I), as displayed in Table 5, results confirm the non-linearity of the wealth-migration relationship. In a context with low network prevalence, the probability to migrate increases with household wealth; when networks are present, this selection effect is weakened, and the wealth-migration relationship is bell-shaped. Individuals come from relatively poorer households when networks grow. 
Table 6 Individual determinants of the emigration decision

\begin{tabular}{|c|c|c|c|c|}
\hline & $\begin{array}{l}\text { (1) } \\
\text { OLS } \\
\text { All } \\
\end{array}$ & $\begin{array}{l}\text { (2) } \\
\text { IV } \\
\text { All }\end{array}$ & $\begin{array}{l}\text { (3) } \\
\text { IV } \\
\text { Urban }\end{array}$ & $\begin{array}{l}(4) \\
\text { IV } \\
\text { Rural } \\
\end{array}$ \\
\hline \multirow[t]{2}{*}{ Network } & $0.441^{* * *}$ & $1.609 * * *$ & 1.773 & $1.687^{* * *}$ \\
\hline & $(0.093)$ & $(0.448)$ & $(1.320)$ & $(0.583)$ \\
\hline \multirow[t]{2}{*}{ Household wealth } & $0.011^{* *}$ & 0.014 & 0.018 & 0.007 \\
\hline & $(0.004)$ & $(0.011)$ & $(0.018)$ & $(0.020)$ \\
\hline \multirow[t]{2}{*}{ Wealth ${ }^{2}$} & $0.006^{* *}$ & $0.019^{* *}$ & $0.017^{*}$ & 0.018 \\
\hline & $(0.003)$ & $(0.009)$ & $(0.010)$ & $(0.016)$ \\
\hline \multirow[t]{2}{*}{ Network $\times$ wealth } & -0.111 & $-0.367^{*}$ & -0.153 & -0.170 \\
\hline & $(0.085)$ & $(0.204)$ & $(0.560)$ & $(0.269)$ \\
\hline \multirow[t]{2}{*}{ Network $\times$ wealth ${ }^{2}$} & $-0.166^{* * *}$ & $-0.518^{* *}$ & $-0.686^{*}$ & -0.383 \\
\hline & $(0.054)$ & $(0.211)$ & $(0.369)$ & $(0.248)$ \\
\hline \multirow[t]{2}{*}{ Primary educ. } & -0.007 & 0.000 & 0.015 & -0.017 \\
\hline & $(0.007)$ & $(0.009)$ & $(0.013)$ & $(0.011)$ \\
\hline \multirow[t]{2}{*}{ Secondary educ. } & $0.025^{* * *}$ & $0.026^{* * *}$ & 0.006 & $0.029^{* *}$ \\
\hline & $(0.010)$ & $(0.010)$ & $(0.010)$ & $(0.014)$ \\
\hline \multirow[t]{2}{*}{ Tertiary educ. } & 0.015 & $0.023^{* *}$ & $0.024^{* *}$ & 0.010 \\
\hline & $(0.009)$ & $(0.010)$ & $(0.011)$ & $(0.016)$ \\
\hline \multirow[t]{2}{*}{ Household size } & -0.000 & -0.000 & -0.001 & -0.000 \\
\hline & $(0.001)$ & $(0.001)$ & $(0.003)$ & $(0.002)$ \\
\hline \multicolumn{5}{|c|}{ Sanderson-Windmeijer F-stat } \\
\hline \multicolumn{2}{|l|}{ Network } & 13.35 & 2.61 & 10.47 \\
\hline \multicolumn{2}{|l|}{ Network $\times$ wealth } & 19.33 & 4.75 & 11.20 \\
\hline \multicolumn{2}{|l|}{ Network $\times$ wealth ${ }^{2}$} & 11.46 & 5.26 & 15.24 \\
\hline \multirow{2}{*}{$\begin{array}{l}\text { Observations } \\
R^{2}\end{array}$} & 8165 & 8165 & 3800 & 4365 \\
\hline & 0.050 & & & \\
\hline
\end{tabular}

Standard errors in parentheses. Linear probability model. Survey-weighted estimations, standard errors clustered at district level. Columns 2-4: network variable is instrumented using old migration rates (based on 1990-1998 departures) in level and

interaction terms. Dependent variable: 1 if individual emigrated between 2007 and 2012. Mean value of the dependent is 0.053 0.069 in rural sample, 0.035 in urban sample. Regressors are observed in 2006. Model includes age controls (indicators for 4 age brackets), urban dummy

${ }^{* * *} p<0.01 ;{ }^{* *} p<0.05 ;{ }^{*} p<0.1$

In columns 2 to 4, we instrument our network variable. As before, we use a measure of older migration rates as an instrument for recent migration: we compute migration rates (the proportion of households with a migrant) at the district level based on departures in 1990-1998 and use it to instrument the migration rate for 1998-2006 departures, which is our measure of the network for an individual considering migration after 2006. In order to reduce measurement error for migration rates, we exclude from the sample districts with less than 25 households surveyed in 2006.

IV results confirm the non-linear relationship between migration propensity and wealth. The IV estimate of the network effect is larger than in OLS, possibly due to measurement error. Results are in line with those from the household model (sample I): coefficients on household-level variables, such as network, wealth, and their interactions are very similar when comparing column 2 in Tables 5 and 6.

The probability to migrate is estimated to be higher by $16 \%$ in a district with a $10 \%$ higher rate of past migrations, all else equal. This effect is reduced by half $(-0.885=$ $-0.367-0.518)$ for an individual whose household is wealthier than the average by one standard deviation (i.e., wealth $=1$ ). In the last two columns, we try to measure differences across urban and rural areas; however, results are subject to caution due to lower statistical power. 
Table 7 Individual determinants of emigration: Labor market factors, OLS results

\begin{tabular}{|c|c|c|c|c|c|c|}
\hline & (1) & (2) & (3) & (4) & (5) & (6) \\
\hline & All & Urban & Rural & \multicolumn{3}{|c|}{ Employed individuals } \\
\hline \multirow[t]{2}{*}{ Network } & $0.431^{* * *}$ & $0.410^{* * *}$ & $0.393^{* * *}$ & $0.385^{* * *}$ & $0.374^{* * *}$ & $0.583^{* * *}$ \\
\hline & $(0.090)$ & $(0.151)$ & $(0.105)$ & $(0.110)$ & $(0.108)$ & $(0.136)$ \\
\hline \multirow[t]{2}{*}{ Household wealth } & $0.010^{* *}$ & $0.018^{* * *}$ & -0.002 & 0.007 & 0.007 & 0.002 \\
\hline & $(0.005)$ & $(0.005)$ & $(0.009)$ & $(0.005)$ & $(0.005)$ & $(0.006)$ \\
\hline \multirow[t]{2}{*}{ Wealth ${ }^{2}$} & $0.007^{* *}$ & $0.006^{*}$ & 0.000 & $0.006^{* *}$ & $0.006^{* *}$ & $0.006^{* *}$ \\
\hline & $(0.003)$ & $(0.004)$ & $(0.006)$ & $(0.003)$ & $(0.003)$ & $(0.003)$ \\
\hline \multirow[t]{2}{*}{ Network $\times$ wealth } & -0.112 & -0.103 & -0.027 & -0.056 & -0.054 & 0.061 \\
\hline & $(0.084)$ & $(0.092)$ & $(0.108)$ & $(0.092)$ & $(0.090)$ & $(0.107)$ \\
\hline \multirow[t]{2}{*}{ Network $\times$ wealth $^{2}$} & $-0.174^{* * *}$ & $-0.249^{* * *}$ & -0.110 & $-0.145^{* *}$ & $-0.141^{* *}$ & $-0.117^{* *}$ \\
\hline & $(0.053)$ & $(0.072)$ & $(0.071)$ & $(0.058)$ & $(0.057)$ & $(0.059)$ \\
\hline \multirow[t]{2}{*}{ Employed } & $0.083^{* * *}$ & $0.065^{* * *}$ & $0.091^{* * *}$ & & & \\
\hline & $(0.011)$ & $(0.010)$ & $(0.017)$ & & & \\
\hline \multirow[t]{2}{*}{ Unemployed } & $0.204^{* * *}$ & $0.106^{* * *}$ & $0.295^{* * *}$ & & & \\
\hline & $(0.023)$ & $(0.023)$ & $(0.035)$ & & & \\
\hline \multirow[t]{2}{*}{ Formal empl. } & & & & $-0.016^{* *}$ & & 0.012 \\
\hline & & & & $(0.008)$ & & $(0.009)$ \\
\hline \multirow[t]{2}{*}{ Formal $\times$ no educ. } & & & & & -0.013 & \\
\hline & & & & & $(0.009)$ & \\
\hline \multirow[t]{2}{*}{ Formal $\times$ primary educ. } & & & & & 0.024 & \\
\hline & & & & & $(0.016)$ & \\
\hline \multirow[t]{2}{*}{ Formal $\times$ secondary educ. } & & & & & $-0.043^{* * *}$ & \\
\hline & & & & & $(0.014)$ & \\
\hline \multirow[t]{2}{*}{ Formal $\times$ tertiary educ. } & & & & & -0.009 & \\
\hline & & & & & $(0.019)$ & \\
\hline \multirow[t]{2}{*}{ Network $\times$ formal } & & & & & & $-0.601^{* * *}$ \\
\hline & & & & & & $(0.140)$ \\
\hline \multirow[t]{2}{*}{ Primary educ. } & -0.006 & 0.009 & $-0.021^{* *}$ & -0.004 & $-0.018^{*}$ & -0.004 \\
\hline & $(0.007)$ & $(0.012)$ & $(0.009)$ & $(0.008)$ & $(0.010)$ & $(0.008)$ \\
\hline \multirow[t]{2}{*}{ Secondary educ. } & $0.022^{* *}$ & 0.007 & $0.023^{*}$ & $0.022^{* *}$ & $0.035^{* *}$ & $0.022^{* *}$ \\
\hline & $(0.010)$ & $(0.010)$ & $(0.013)$ & $(0.011)$ & $(0.015)$ & $(0.011)$ \\
\hline \multirow[t]{2}{*}{ Tertiary educ. } & $0.020^{* *}$ & $0.024^{* *}$ & 0.010 & $0.023^{* *}$ & 0.018 & $0.022^{*}$ \\
\hline & $(0.009)$ & $(0.010)$ & $(0.014)$ & $(0.011)$ & $(0.019)$ & $(0.011)$ \\
\hline \multirow[t]{2}{*}{ Household size } & 0.000 & 0.001 & 0.000 & 0.000 & 0.000 & 0.000 \\
\hline & $(0.001)$ & $(0.003)$ & $(0.001)$ & $(0.001)$ & $(0.001)$ & $(0.001)$ \\
\hline Observations & 8165 & 3800 & 4365 & 6159 & 6159 & 6159 \\
\hline$R^{2}$ & 0.084 & 0.054 & 0.106 & 0.057 & 0.060 & 0.064 \\
\hline
\end{tabular}

Standard errors in parentheses. Linear probability model. Survey-weighted estimations, standard errors clustered at district level. Dependent variable: 1 if individual emigrated between 2007 and 2012. Mean value of the dependent is $0.053,0.069$ in rural sample, 0.035 in urban sample. Regressors are observed in 2006. Model includes age controls (indicators for 4 age brackets), urban dummy. Employed and unemployed are binary variables, the omitted reference category is inactive (students and other non-participating individuals). Education has four categories, the reference group is individuals with no education ${ }^{* * *} p<0.01 ; * * 0.05 ; * p<0.1$ 
Table 8 Individual determinants of emigration: Labor market factors, IV results

\begin{tabular}{|c|c|c|c|c|c|c|}
\hline & $\begin{array}{l}(1) \\
\text { All }\end{array}$ & $\begin{array}{l}(2) \\
\text { Urban }\end{array}$ & $\begin{array}{l}\text { (3) } \\
\text { Rural } \\
\end{array}$ & \multicolumn{3}{|c|}{ Employed individuals } \\
\hline Network & $\begin{array}{l}1.561^{* * *} \\
(0.453)\end{array}$ & $\begin{array}{l}1.935 \\
(1.406)\end{array}$ & $\begin{array}{l}1.574^{* * *} \\
(0.571)\end{array}$ & $\begin{array}{l}1.350^{* * *} \\
(0.460)\end{array}$ & $\begin{array}{l}1.371 * * * \\
(0.477)\end{array}$ & $\begin{array}{l}2.883^{* * * *} \\
(0.970)\end{array}$ \\
\hline Household wealth & $\begin{array}{l}0.015 \\
(0.012)\end{array}$ & $\begin{array}{l}0.022 \\
(0.018)\end{array}$ & $\begin{array}{l}0.008 \\
(0.020)\end{array}$ & $\begin{array}{l}0.019 \\
(0.016)\end{array}$ & $\begin{array}{l}0.019 \\
(0.016)\end{array}$ & $\begin{array}{l}-0.030 \\
(0.029)\end{array}$ \\
\hline Wealth $^{2}$ & $\begin{array}{l}0.019 * * \\
(0.009)\end{array}$ & $\begin{array}{l}0.017 \\
(0.011)\end{array}$ & $\begin{array}{l}0.019 \\
(0.016)\end{array}$ & $\begin{array}{l}0.019 * * \\
(0.010)\end{array}$ & $\begin{array}{l}0.025^{* *} \\
(0.010)\end{array}$ & $\begin{array}{l}0.018^{*} \\
(0.011)\end{array}$ \\
\hline Network $\times$ wealth & $\begin{array}{l}-0.384^{*} \\
(0.217)\end{array}$ & $\begin{array}{l}-0.248 \\
(0.567)\end{array}$ & $\begin{array}{l}-0.240 \\
(0.288)\end{array}$ & $\begin{array}{l}-0.110 \\
(0.315)\end{array}$ & $\begin{array}{l}-0.128 \\
(0.338)\end{array}$ & $\begin{array}{l}0.941 \\
(0.666)\end{array}$ \\
\hline Network $\times$ wealth ${ }^{2}$ & $\begin{array}{l}-0.509^{* *} \\
(0.212)\end{array}$ & $\begin{array}{l}-0.669 * \\
(0.382)\end{array}$ & $\begin{array}{l}-0.407^{*} \\
(0.246)\end{array}$ & $\begin{array}{l}-0.518^{* *} \\
(0.218)\end{array}$ & $\begin{array}{l}-0.543^{* *} \\
(0.240)\end{array}$ & $\begin{array}{l}-0.291 \\
(0.271)\end{array}$ \\
\hline Employed & $\begin{array}{l}0.084^{* * *} \\
(0.011)\end{array}$ & $\begin{array}{l}0.063^{* * *} \\
(0.010)\end{array}$ & $\begin{array}{l}0.095^{* * *} \\
(0.017)\end{array}$ & & & \\
\hline Unemployed & $\begin{array}{l}0.200^{* * *} \\
(0.023)\end{array}$ & $\begin{array}{l}0.112^{* * *} \\
(0.023)\end{array}$ & $\begin{array}{l}0.283^{* * *} \\
(0.035)\end{array}$ & & & \\
\hline Formal empl. & & & & $\begin{array}{l}-0.277^{* *} \\
(0.121)\end{array}$ & & $\begin{array}{l}0.007 \\
(0.168)\end{array}$ \\
\hline Formal $\times$ no educ. & & & & & $\begin{array}{l}-0.028 \\
(0.103)\end{array}$ & \\
\hline Formal × primary educ. & & & & & $\begin{array}{l}-0.106 \\
(0.111)\end{array}$ & \\
\hline Formal × secondary educ. & & & & & $\begin{array}{l}-0.430^{* * *} \\
(0.158)\end{array}$ & \\
\hline Formal × tertiary educ. & & & & & $\begin{array}{l}-0.526^{*} \\
(0.289)\end{array}$ & \\
\hline Network $\times$ formal & & & & & & $\begin{array}{l}-4.926^{*} \\
(2.866)\end{array}$ \\
\hline Primary educ. & $\begin{array}{l}0.001 \\
(0.009)\end{array}$ & $\begin{array}{l}0.015 \\
(0.014)\end{array}$ & $\begin{array}{l}-0.014 \\
(0.011)\end{array}$ & $\begin{array}{l}0.036^{*} \\
(0.020)\end{array}$ & $\begin{array}{l}0.036 \\
(0.037)\end{array}$ & $\begin{array}{l}0.034 \\
(0.021)\end{array}$ \\
\hline Secondary educ. & $\begin{array}{l}0.023^{* *} \\
(0.010)\end{array}$ & $\begin{array}{l}0.004 \\
(0.011)\end{array}$ & $\begin{array}{l}0.023^{*} \\
(0.014)\end{array}$ & $\begin{array}{l}0.086^{* *} \\
(0.035)\end{array}$ & $\begin{array}{l}0.216^{* * *} \\
(0.072)\end{array}$ & $\begin{array}{l}0.073^{* *} \\
(0.037)\end{array}$ \\
\hline Tertiary educ. & $\begin{array}{l}0.029^{* * *} \\
(0.011)\end{array}$ & $\begin{array}{l}0.026^{* *} \\
(0.011)\end{array}$ & $\begin{array}{l}0.019 \\
(0.016)\end{array}$ & $\begin{array}{l}0.133^{* *} \\
(0.052)\end{array}$ & $\begin{array}{l}0.375 * \\
(0.200)\end{array}$ & $\begin{array}{l}0.105^{* *} \\
(0.053)\end{array}$ \\
\hline Household size & $\begin{array}{l}0.000 \\
(0.001)\end{array}$ & $\begin{array}{l}-0.000 \\
(0.003)\end{array}$ & $\begin{array}{l}0.000 \\
(0.002)\end{array}$ & $\begin{array}{l}-0.003 \\
(0.002)\end{array}$ & $\begin{array}{l}-0.003 \\
(0.002)\end{array}$ & $\begin{array}{l}-0.003 \\
(0.002)\end{array}$ \\
\hline Sanderson-Windmeijer F-st & & & & & & \\
\hline Network & 13.29 & 2.68 & 10.34 & 18.88 & 22.08 & 6.69 \\
\hline Network $\times$ wealth & 19.34 & 4.78 & 11.23 & 22.30 & 25.20 & 7.24 \\
\hline Network $\times$ wealth ${ }^{2}$ & 11.47 & 5.36 & 15.18 & 11.23 & 11.69 & 9.94 \\
\hline Formal & & & & 16.95 & & 11.45 \\
\hline Network $\times$ formal & & & & & & 5.10 \\
\hline Formal × no educ. & & & & & 15.78 & \\
\hline Formal $\times$ primary educ. & & & & & 25.65 & \\
\hline Formal × secondary educ. & & & & & 16.53 & \\
\hline Formal $\times$ tertiary educ. & & & & & 15.30 & \\
\hline Observations & 8165 & 3800 & 4365 & 6159 & 6159 & 6159 \\
\hline
\end{tabular}

Standard errors in parentheses. Linear probability model. Survey-weighted estimations, standard errors clustered at district level. Dependent variable: 1 if individual emigrated between 2007 and 2012. Mean value of the dependent is 0.053, 0.069 in rural sample, 0.035 in urban sample. Regressors are observed in 2006. Model includes age controls (indicators for 4 age brackets), urban dummy. Employed and unemployed are binary variables, the omitted reference category is inactive (students and other non-participating individuals). Education has four categories, the reference group is individuals with no education ${ }^{* * *} p<0.01,{ }^{* *} p<0.05,{ }^{*} p<0.1$ 
In Tables 7 and 8, we test the impact of individual labor market outcomes on the probability to emigrate, in OLS and IV. In columns 1-3, the impact of being employed and unemployed, respectively, is measured with respect to the reference group of inactives (students and other non-participating individuals). Being unemployed is a strong predictor of emigration, with the impact being larger in rural areas. For example, being unemployed is associated with a 19 percentage points higher probability to emigrate than for an employed person $(0.188=0.283-0.095$, IV results $)$ in rural areas. This confirms the role played by the Egyptian labor market conditions, characterized by a scarcity of jobs, as an incentive to migrate.

In columns 4-6 of the tables, we look further at the role of labor market outcomes in the migration decision. We restrict the sample to employed individuals and consider the role of formal employment in the migration decision. Formality is negatively associated with the propensity to migrate; the impact is larger when instrumenting formal employment using an indicator for whether the individual's father was employed in the public sector at age 15 of the son ${ }^{14}$. There is a strong correlation between father's public employment and son's employment in the formal sector. Our assumption is that, once controlling for household wealth and structure and individual education, a father's past public employment does not influence the decision to migrate other than through a higher probability of securing formal employment for the son.

Results in column 5 indicate that the impact of formality is concentrated among the secondary and tertiary educated. This suggests that the scarcity of "quality" jobs faced by skilled individuals may explain part of the positive selection of migrants which is a specific feature of Egypt (Marchetta 2012).

Results in column 6 indicate that the effect is stronger in areas with high migration prevalence, consistent with the hypothesis that informal employment acts as an incentive to emigrate, while access to a network of past migrants reduces the cost of migration (the two variables thus acting as complements).

We check that results from Tables 6, 7, and 8 hold when using a probit or IV-probit model; these results are reported in the Appendix.

\section{Conclusions}

Egypt is considered the largest labor exporter in the Middle East (Wahba 2009). Numerous studies have studied the returns to migration, in particular upon return (Wahba 2007; Wahba and Zenou 2012), as well as the impacts on the family left behind (Binzel and Assaad 2011). Less attention has been devoted to the selection of emigrants. In this paper, we ask to what extent deteriorating prospects on the labor market drive decisions to emigrate. We also ask whether migration costs may constrain migration choices, making migration conditional on wealth or access to a network of past migrants. The relationship between wealth and migration matters for the impact of migration on inequality in origin communities, as shown in McKenzie and Rapoport (2007).

Using three rounds of recent data from Egypt's labor market survey, we analyze the determinants of the decision to emigrate abroad, at the household and individual level. The panel structure of the data allows us to mitigate endogeneity issues, when measuring the impact of wealth and migrant networks, on the propensity to emigrate, by using predeparture values of these variables. We devote particular attention to the role of labor market outcomes, i.e., unemployment and informality, in the migration decision. 
We first confirm the non-linearity of the relationship between wealth and migration, in the context of Egypt, in line with McKenzie and Rapoport (2007); Fernandez-Huertas Moraga (2013). The propensity to emigrate is highest among individuals who come from households in the middle-lower part of the wealth distribution. This is consistent with the hypothesis that incentives to migrate are higher among poorer households, but that migration costs, in the presence of liquidity constraints, positively select migrants on wealth. We find that a larger network of past migrants from the same community tends to favor migration and to lower the level of wealth necessary to afford migration.

Second, we identify labor market outcomes as one important driver of emigration. Unemployed young men are relatively more likely to emigrate, as are those employed in the informal sector. In the context of Egypt, with rationing on the skilled labor market (Assaad 2014), these results indicate that the lack of perspectives in the country for the young is one driver of migration flows. This is the case in particular among the educated young, and in rural areas, potentially more distant from formal job opportunities (World Bank 2014). Interacting labor market outcomes with our measure of migrant networks shows that migration decisions are conditional on the network: the effect of unemployment and informal employment is non-significant or reversed in areas with a low prevalence of migration. This raises the potential concern that opportunities to migrate are unequally shared across communities in Egypt.

\section{Endnotes}

${ }^{1}$ This implies that migration is expected to increase inequality in areas with low networks, as shown in McKenzie and Rapoport (2007).

${ }^{2}$ They usually hold a restrictive, temporary work permit, under the kafala system. Wahba (2014) draws a complete overview of the patterns and trends of Egyptian international migration.

${ }^{3}$ For a detailed description of the ELMPS data, see Assaad (2014) and Barssoum (2007).

${ }^{4}$ Those aged 45 to 54 make up $4.5 \%$ of the sample, while those 55 or older represent less than $1.5 \%$ of all migrants. This is why we decided to restrict the sample to individuals aged 16 to 54 in 2006.

${ }^{5}$ McKenzie and Rapoport (2007) study the impact of migration on inequality in sending communities. In the first part of their empirical analysis, they estimate a model of migration with household resources (non-durable consumption) and networks (migration prevalence) as determinants. Our model is similar, except for timing (we use pre-departure determinants); however, our focus is not on the migration-inequality link contrary to theirs.

${ }^{6}$ Data on expenditure are not available in the survey.

${ }^{7}$ One possibility of reverse causation is that the household prepares the migration episode by saving money or selling assets, which would bias downward the coefficient estimate on wealth. In unreported results, we compare our model to a simultaneous model, similar to the one used in McKenzie and Rapoport (2007), in which recent migration episodes (not older than 1 year) are regressed on household wealth. We find larger coefficient on wealth in our lagged model, which confirms the downward bias in the simultaneous model.

${ }^{8}$ For $t=2006$, we use the migration rate for the 1998-2005 period; for $t=1998$, the 1990-1997 period. 
${ }^{9}$ Gruntz (2014) shows, in her work on Egyptian migrants in the UAE, the role played by the Egyptian communities already in place in providing logistical help to newcomers.

${ }^{10}$ Similarly, for $t=1998$, we instrument the 1990-1997 migration prevalence with the one based on pre-1990 departures.

${ }^{11}$ Migration costs are here intended to include both monetary and non-monetary costs, such as informational costs related to the journey and to labor markets at destination (Munshi 2003). In the case of Egypt, Zohry A (2004) quotes figures for the price paid to brokers to obtain a work contract in Gulf countries.

${ }^{12}$ Note that, in order to mitigate measurement error, we have excluded from the sample all districts where less than 20 households had been surveyed.

${ }^{13}$ Based on coefficients in column 3, at the mean network value of 0.031 , migration propensity reaches its maximum at a wealth level given by $(0.017-0.377 *$ $0.031)+2 .(0.016-0.563 * 0.031) * W=0$, which yields $W=1.82$. Thus, it is increasing in wealth on most of the support of this variable, which is standardized and does not exceed 3.5. With a network value twice higher, the maximum is reached at -0.15 .

${ }^{14}$ The question asks for the father's last employment if he was dead or unemployed at age 15 of the individual.

\section{Appendix}

\subsection{Household model (sample I): probit estimations}

Table 9 Household determinants of the probability to send a migrant

\begin{tabular}{|c|c|c|c|c|c|c|}
\hline & (1) & $(2)$ & (3) & (4) & (5) & (6) \\
\hline & OLS & IV & OLS & IV & IV & IV \\
\hline & & & & & urban & rural \\
\hline \multirow[t]{2}{*}{ Network } & $0.166^{* * *}$ & $0.932 * * *$ & $0.177^{* * *}$ & $0.903^{* * *}$ & $0.678^{*}$ & $1.216^{* * *}$ \\
\hline & $(0.059)$ & $(0.306)$ & $(0.059)$ & $(0.294)$ & $(0.390)$ & $(0.467)$ \\
\hline \multirow[t]{2}{*}{ Wealth } & $0.018^{* * *}$ & $0.024^{* * *}$ & $0.016^{* * *}$ & $0.022^{* * *}$ & $0.029^{* * *}$ & $0.018^{*}$ \\
\hline & $(0.003)$ & $(0.006)$ & $(0.003)$ & $(0.006)$ & $(0.008)$ & $(0.010)$ \\
\hline \multirow[t]{2}{*}{ Network $\times$ wealth } & -0.037 & -0.174 & -0.042 & $-0.197^{*}$ & $-0.555^{* *}$ & -0.107 \\
\hline & $(0.036)$ & $(0.108)$ & $(0.038)$ & $(0.112)$ & $(0.251)$ & $(0.139)$ \\
\hline \multirow[t]{2}{*}{ Household size } & $0.004^{* * *}$ & $0.005^{* * *}$ & $0.005^{* * *}$ & $0.005^{* * *}$ & $0.005^{* * *}$ & $0.006^{* * *}$ \\
\hline & $(0.001)$ & $(0.001)$ & $(0.001)$ & $(0.001)$ & $(0.001)$ & $(0.002)$ \\
\hline \multirow[t]{2}{*}{ Share of working-age men } & & & $0.109^{* * *}$ & $0.126^{* * *}$ & $0.071^{* * *}$ & $0.188^{* * *}$ \\
\hline & & & $(0.015)$ & $(0.017)$ & $(0.016)$ & $(0.032)$ \\
\hline \multirow[t]{2}{*}{ Dependency rate } & & & $0.030^{* *}$ & $0.044^{* * *}$ & $0.041^{* *}$ & $0.061^{* *}$ \\
\hline & & & $(0.013)$ & $(0.015)$ & $(0.019)$ & $(0.026)$ \\
\hline \multirow[t]{2}{*}{ Yrs of schooling, HH. head } & 0.000 & 0.000 & 0.001 & 0.001 & 0.000 & 0.002 \\
\hline & $(0.001)$ & $(0.001)$ & $(0.001)$ & $(0.001)$ & $(0.001)$ & $(0.001)$ \\
\hline \multirow[t]{2}{*}{ Male hh. head } & -0.008 & -0.008 & $-0.017^{* * *}$ & $-0.018^{* * *}$ & $-0.023^{* * *}$ & -0.011 \\
\hline & $(0.006)$ & $(0.007)$ & $(0.006)$ & $(0.007)$ & $(0.008)$ & $(0.012)$ \\
\hline \multirow[t]{2}{*}{ Formal employment } & $-0.032^{*}$ & -0.027 & $-0.040^{* *}$ & -0.031 & 0.014 & $-0.097^{* * *}$ \\
\hline & $(0.018)$ & $(0.019)$ & $(0.018)$ & $(0.020)$ & $(0.022)$ & $(0.034)$ \\
\hline Observations & 10,219 & 10,219 & 10,219 & 10,219 & 5875 & 4343 \\
\hline
\end{tabular}

Marginal effects at mean of regressors. Standard errors in parentheses. Survey weighted probit/IV-probit model, standard errors clustered at district level. Two-wave panel sample of households. Regressors are observed in $t=1998,2006$. Dependent variable is 1 if a member of the household emigrated after $t$. The mean value of the dependent variable is 0.045 . Model includes urban and year indicator variables, governorate fixed-effects. IV: network variable is instrumented using old migration rates (based on pre-1998 departures when $t=2006$, pre-1990 when $t=1998$ ) in level and interaction terms

${ }^{* * *} p<0.01,{ }^{* *} p<0.05,{ }^{*} p<0.1$ 
Table 10 Determinants of migration: unemployment and formality (IV estimates)

\begin{tabular}{lll}
\hline & $(1)$ & $(2)$ \\
\hline Network & $0.857^{* * *}$ & $0.894^{* * *}$ \\
Wealth & $(0.281)$ & $(0.250)$ \\
& $0.013^{* * *}$ & $0.013^{* * *}$ \\
Unemployment (share) & $(0.003)$ & $(0.003)$ \\
& $-0.093^{* *}$ & $-0.092^{* *}$ \\
Unemp. $\times$ network & $(0.046)$ & $(0.046)$ \\
& $2.625^{* *}$ & $2.581^{* *}$ \\
Formal employment & $(1.204)$ & $(1.202)$ \\
Formal $\times$ network & $-0.033^{*}$ & 0.005 \\
& $(0.019)$ & $(0.034)$ \\
Household size & & -1.083 \\
Share of working-age men & & $(0.921)$ \\
Years of schooling, HH. head & $0.005^{* * *}$ & $0.005^{* * *}$ \\
Observations & $(0.001)$ & $(0.001)$ \\
\hline Margna & $0.125^{* * *}$ & $0.126^{* * *}$ \\
& $(0.018)$ & $(0.018)$ \\
& 0.001 & 0.001 \\
& $(0.001)$ & $(0.001)$ \\
& 10219 & 10219 \\
\hline
\end{tabular}

Marginal effects at mean of regressors. Standard errors in parentheses. Survey weighted probit/lV-probit model, standard errors clustered at district level. Two-wave panel sample of households. Regressors are observed in $t=1998$, 2006. Dependent variable is 1 if a member of the household emigrated after $t$. The mean value of the dependent variable is 0.045 . Model includes governorate fixed-effects and the controls: urban, year, dependency, share of working-age men, Male hh. head. IV: network variable is instrumented using old migration rates (based on pre-1998 departures when $t=2006$, pre-1990 when $t=1998$ ) in level and interaction terms

${ }^{* * *} p<0.01,{ }^{* *} p<0.05,{ }^{*} p<0.1$ 
Table 11 Household determinants of the probability to send a migrant

\begin{tabular}{|c|c|c|c|c|}
\hline & $(1)$ & $(2)$ & (3) & (4) \\
\hline & OLS & IV & IV & IV \\
\hline & & & Urban & Rural \\
\hline \multirow[t]{2}{*}{ Network } & $0.249^{* * *}$ & $1.163^{* * *}$ & $1.101^{* *}$ & $1.358^{* * *}$ \\
\hline & $(0.066)$ & $(0.324)$ & $(0.552)$ & $(0.480)$ \\
\hline \multirow[t]{2}{*}{ Wealth } & $0.017^{* * *}$ & $0.020^{* * *}$ & $0.020^{* *}$ & 0.015 \\
\hline & $(0.003)$ & $(0.006)$ & $(0.009)$ & $(0.011)$ \\
\hline \multirow[t]{2}{*}{ Wealth² } & $0.004^{*}$ & $0.013^{* *}$ & 0.013 & 0.005 \\
\hline & $(0.002)$ & $(0.005)$ & $(0.011)$ & $(0.009)$ \\
\hline \multirow[t]{2}{*}{ Network $\times$ Wealth } & $-0.130^{* * *}$ & $-0.387^{* *}$ & -0.153 & -0.293 \\
\hline & $(0.049)$ & $(0.168)$ & $(0.236)$ & $(0.188)$ \\
\hline \multirow[t]{2}{*}{ Network $\times$ wealth ${ }^{2}$} & $-0.145^{* * *}$ & $-0.450^{* * *}$ & -0.617 & $-0.333^{* *}$ \\
\hline & $(0.037)$ & $(0.162)$ & $(0.409)$ & $(0.152)$ \\
\hline \multirow[t]{2}{*}{ Household size } & $0.005^{* * *}$ & $0.005^{* * *}$ & $0.005^{* * *}$ & $0.006^{* * *}$ \\
\hline & $(0.001)$ & $(0.001)$ & $(0.001)$ & $(0.002)$ \\
\hline \multirow[t]{2}{*}{ Share of working-age men } & $0.110^{* * *}$ & $0.125^{* * *}$ & $0.076^{* * *}$ & $0.183^{* * *}$ \\
\hline & $(0.015)$ & $(0.017)$ & $(0.019)$ & $(0.031)$ \\
\hline \multirow[t]{2}{*}{ Dependency rate } & $0.032^{* *}$ & $0.047^{* * *}$ & $0.047^{* *}$ & $0.061^{* *}$ \\
\hline & $(0.013)$ & $(0.016)$ & $(0.021)$ & $(0.027)$ \\
\hline \multirow[t]{2}{*}{ Years of schooling, $\mathrm{HH}$. head } & 0.001 & 0.001 & 0.000 & $0.002^{*}$ \\
\hline & $(0.001)$ & $(0.001)$ & $(0.001)$ & $(0.001)$ \\
\hline \multirow[t]{2}{*}{ Male hh. head } & $-0.017^{* * *}$ & $-0.017^{* *}$ & $-0.024^{* * *}$ & -0.011 \\
\hline & $(0.006)$ & $(0.007)$ & $(0.009)$ & $(0.011)$ \\
\hline \multirow[t]{2}{*}{ Formal employment } & $-0.038^{* *}$ & -0.026 & 0.015 & $-0.085^{* *}$ \\
\hline & $(0.018)$ & $(0.020)$ & $(0.023)$ & $(0.034)$ \\
\hline Observations & 10219 & 10219 & 5875 & 4343 \\
\hline
\end{tabular}

Marginal effects at mean of regressors. Standard errors in parentheses. Survey weighted probit/iv-probit model, standard errors clustered at district level. Two-wave panel sample of households. Regressors are observed in $t=1998,2006$. Dependent variable is 1 if a member of the household emigrated after $t$. The mean value of the dependent variable is 0.045 . Model includes governorate fixed-effects, urban dummy (col. 1-2), year dummy. IV: network variable is instrumented using old migration rates (based on pre-1998 departures when $t=2006$, pre-1990 when $t=1998$ ) in level and interaction terms ${ }^{* * *} p<0.01 ; * * 0.05 ; * p<0.1$ 


\subsection{Individual model (sample II): probit estimations}

Table 12 Individual determinants of the emigration decision

\begin{tabular}{|c|c|c|c|c|}
\hline & (1) & (2) & (3) & (4) \\
\hline & OLS & IV & IV & IV \\
\hline & All & All & Urban & Rural \\
\hline \multirow[t]{2}{*}{ Network } & $0.304^{* * *}$ & $1.052^{* *}$ & 1.271 & $1.251^{* *}$ \\
\hline & $(0.061)$ & $(0.415)$ & $(1.335)$ & $(0.587)$ \\
\hline \multirow[t]{2}{*}{ Household wealth } & $0.013^{* * *}$ & $0.014^{*}$ & 0.039 & 0.003 \\
\hline & $(0.005)$ & $(0.008)$ & $(0.025)$ & $(0.018)$ \\
\hline \multirow[t]{2}{*}{ Wealth² } & $0.006^{* *}$ & $0.013^{*}$ & 0.000 & 0.010 \\
\hline & $(0.003)$ & $(0.007)$ & $(0.009)$ & $(0.016)$ \\
\hline \multirow[t]{2}{*}{ Network $\times$ wealth } & -0.097 & $-0.234^{*}$ & -0.526 & -0.073 \\
\hline & $(0.063)$ & $(0.141)$ & $(0.552)$ & $(0.211)$ \\
\hline \multirow[t]{2}{*}{ Network $\times$ wealth $^{2}$} & $-0.113^{* *}$ & $-0.307^{*}$ & -0.248 & -0.226 \\
\hline & $(0.046)$ & $(0.172)$ & $(0.321)$ & $(0.222)$ \\
\hline \multirow[t]{2}{*}{ Primary education } & -0.011 & -0.005 & 0.019 & $-0.019^{* *}$ \\
\hline & $(0.008)$ & $(0.007)$ & $(0.020)$ & $(0.009)$ \\
\hline \multirow[t]{2}{*}{ Secondary educ. } & $0.023^{* * *}$ & $0.020^{* *}$ & 0.014 & $0.023^{*}$ \\
\hline & $(0.009)$ & $(0.008)$ & $(0.012)$ & $(0.012)$ \\
\hline \multirow[t]{2}{*}{ Tertiary educ. } & 0.015 & $0.020^{* *}$ & 0.026 & 0.008 \\
\hline & $(0.009)$ & $(0.010)$ & $(0.016)$ & $(0.014)$ \\
\hline \multirow[t]{2}{*}{ Household size } & 0.000 & -0.000 & 0.000 & -0.000 \\
\hline & $(0.001)$ & $(0.001)$ & $(0.003)$ & $(0.001)$ \\
\hline Observations & 8136 & 8136 & 3738 & 4365 \\
\hline
\end{tabular}

Marginal effects at mean of regressors. Standard errors in parentheses. Survey weighted probit/IV-probit model. Network variable is instrumented using old migration rates (based on 1990-1998 departures) in level and interaction terms. Dependent variable: 1 if individual emigrated between 2006 and 2012. Regressors are observed in 2006. Sample: men aged 16 to 54 in 2006. Districts with less than 25 households surveyed in 2006 are excluded. Model includes age controls (indicators for 4 age brackets), urban dummy ${ }^{* * *} p<0.01 ; * * p<0.05 ;{ }^{*} p<0.1$ 
Table 13 Individual determinants of emigration: Labor market factors

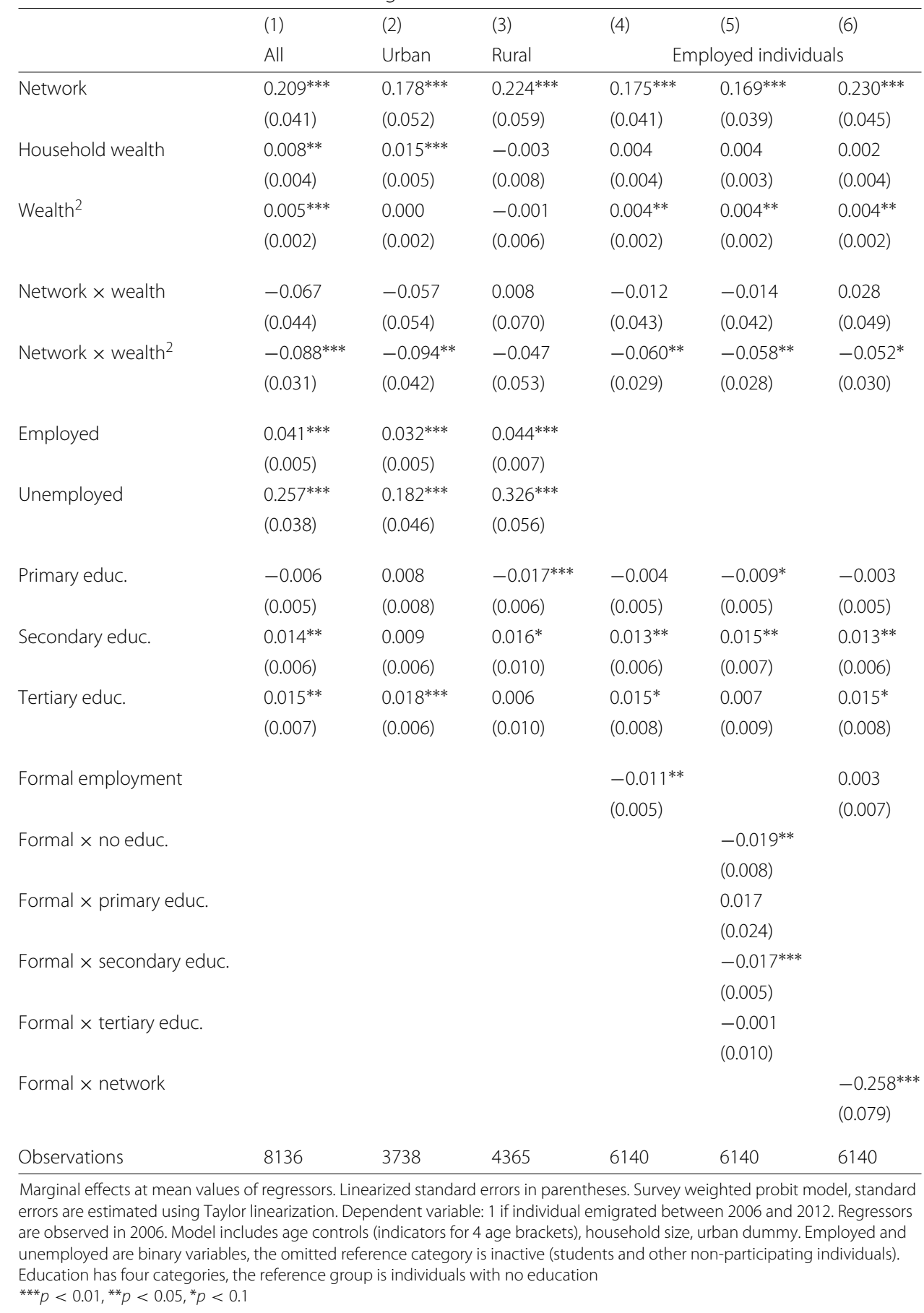


Table 14 Individual determinants of emigration: labor market factors, IV results

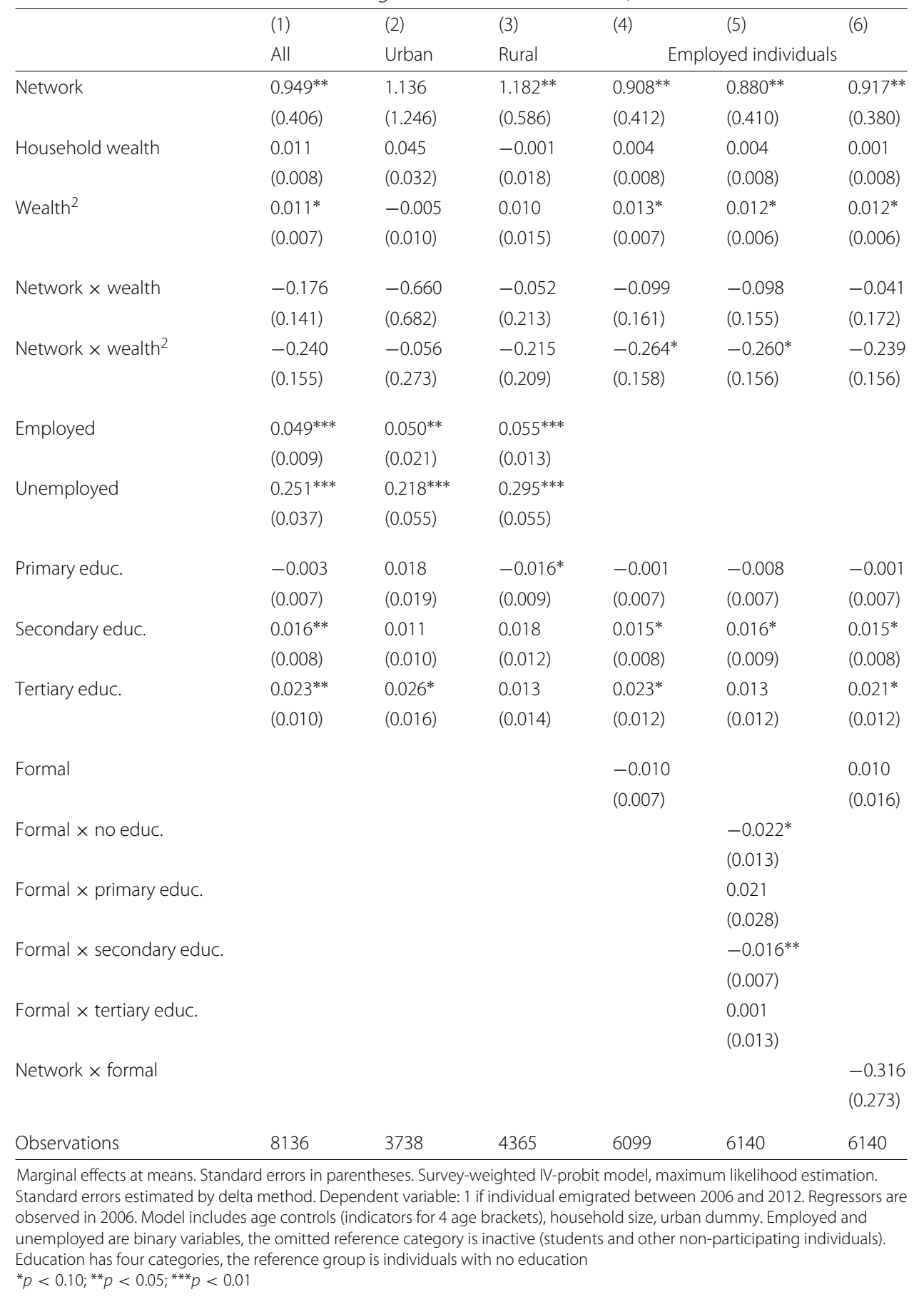




\section{Acknowledgements}

We would like to thank an anonymous reviewer for very detailed and useful comments which helped improve the paper. We gratefully acknowledge financial support from the Economic research forum (ERF) for this work, as part of its project "The use of online harmonized household survey data".

Responsible editor: Denis Fougère

\section{Funding}

This study was partly funded by the Economic Research Forum (grant "The use of harmonized household surveys data", number 2014-042).

\section{Authors' contributions}

$\mathrm{AD}$ and $\mathrm{JJ}$ conducted the empirical analysis and wrote the paper. Both authors read and approved the final manuscript.

\section{Competing interests}

The IZA Journal of Migration is committed to the IZA Guiding Principles of Research Integrity. The authors declare that they have observed these principles.

\section{Author details}

${ }^{1}$ PSL Université Paris-Dauphine, PSL Research university, IRD, LEDa, UMR[225], DIAL, 75016 Paris, France. ${ }^{2}$ Agence Française de Développement, Paris, France.

Received: 29 June 2016 Accepted: 16 December 2016

Published online: 29 June 2017

\section{References}

Amer M, Fargues P (2014) Labour market outcomes and Egypt's migration potential, San Domenico di Fiesole : European University Institute - RSCAS - MPC:32

Assaad R (2014) Making sense of Arab labor markets: the enduring legacy of dualism. IZA Journal of Labor \& Development 3(1):6. doi:10.1186/2193-9020-3-6

Assaad R, Krafft C (2015) The evolution of labor supply and unemployment in the egyptian economy: 1988-2012. In: Assaad R, Krafft C (eds). The Egyptian Labor Market in an Era of Revolution. Oxford University Press

Barssoum G (2007) Egypt labour market panel survey 2006: report on methodology and data collection. ERF working paper, $n^{\circ} 704$, Economic research forum (ERF)

Bertoli S, Marchetta F (2015) Bringing it all back home-return migration and fertility choices. World Development 65:27-40

Binzel C, Assaad R (2011) Egyptian men working abroad: labour supply responses by the women left behind. Labour Economics 18(supp 1):S98-S114

Borjas GJ (1987) Self-selection and the earnings of immigrants. American Economic Review 77(4):531-53

Chiquiar D, Hanson GH (2005) International migration, self-selection, and the distribution of wages: evidence from Mexico and the United States. Journal of Political Economy 113(2):239-281

Fernandez-Huertas Moraga J (2013) Understanding different migrant selection patterns in rural and urban Mexico. Journal of Development Economics 103(C):182-201

Filmer D, Pritchett LH (2001) Estimating wealth effects without expenditure data-or tears: an application to educational enrollments in states of India*. Demography 38(1):115-132

Gruntz L (2014) Des chercheurs d'or aux diplômés chômeurs: émigration, travail et politique entre égypte et golfe (2006-2012). Politique africaine 1(N¹33):93-110

Marchetta F (2012) The impact of migration on the labor markets in the Arab mediterranean countries. Middle East Development Journal 4(1):1-47

McCormick B, Wahba J (2001) Overseas work experience, savings and entrepreneurship amongst return migrants to LDCs. Scottish journal of political economy 48(2):164-178

McCormick, B, Wahba J (2003) Return international migration and geographical inequality: the case of Egypt. Journal of African Economies 12(4):500-532

McKenzie D, Rapoport H (2007) Network effects and the dynamics of migration and inequality: theory and evidence from mexico. Journal of development Economics 84(1):1-24

McKenzie, D, Rapoport H (2010) Self-selection patterns in mexico-us migration: the role of migration networks. The Review of Economics and Statistics 92(4):811-821

Moraga JF-H (2011) New evidence on emigrant selection. The Review of Economics and Statistics 93(1):72-96

Munshi K (2003) Networks in the modern economy: Mexican migrants in the U. S. labor market. The Quarterly Journal of Economics 118(2):549-599

Munshi, K (2015) Community Networks and Migration. In: Bramoullé J, Galeotti A, Rogers BW (eds). Oxford Handbook on the Economics of Networks. Oxford University Press, Oxford

OAMDI (2016) Harmonized labor force surveys (HLFS) version 1.0 of licensed data files. http://www.erfdataportal.com/ index.php/catalog. Accessed 01 Oct 2017

Wahba J (2007) Returns to Overseas Work Experience: The Case of Egypt in International Migration, Economic Development \& Policy. In: Ozden C, Schiff M (eds). The World Bank, Washington DC. pp 235-58

Wahba, J (2009) An overview of internal and international migration in Egypt. In: Assaad R (ed). Egypt's Labor Market Revisited, Ch. 5. The American University in Cairo Press

Wahba J (2014) Through the Keyhole: International Migration in Egypt, ERF working paper, n704, January 2007, Economic research forum (ERF)

Wahba, J (2015) Selection, selection, selection: the impact of return migration. Journal of Population Economics 28(3):535-563 
Wahba J, Assaad R (2015) Flexible labor regulations and informality in Egypt. In: Cairo, Egypt: Economic Research Forum (ERF), 593 Working Paper. Number 915

Wahba J, Zenou Y (2012) Out of sight, out of mind: migration, entrepreneurship and social capital. Regional Science and Urban Economics 42(5):890-903

World Bank (2014) More Jobs, Better Jobs : A Priority for Egypt. Washington, DC. ๑ World Bank. https://openknowledge. worldbank.org/handle/10986/20584 License: CC BY 3.0 IGO

Zohry A (2004) Interrelationships between internal and international migration in Egypt: a pilot study, Research Reports Series, Development Research Center on Migration, Globalization, and Poverty, University of Sussex

Submit your manuscript to a SpringerOpen ${ }^{\circ}$ journal and benefit from:

$\checkmark$ Convenient online submission

- Rigorous peer review

- Immediate publication on acceptance

- Open access: articles freely available online

- High visibility within the field

- Retaining the copyright to your article

Submit your next manuscript at $\boldsymbol{\wedge}$ springeropen.com 